\title{
MUCH ADO ABOUT NEWSGATHERING: PERSONAL PRIVACY, LAW ENFORCEMENT, AND THE LAW OF UNINTENDED CONSEQUENCES FOR ANTI-PAPARAZZI LEGISLATION
}

\begin{abstract}
ANDREW D. MORTON ${ }^{\dagger}$
Experience should teach us to be most on our guard to protect liberty when the Government's purposes are beneficent. Men born to freedom are naturally alert to repel invasion of their liberty by evil-minded rulers. The greatest dangers to liberty lurk in insidious encroachment by men of zeal, well-meaning but without understanding.
\end{abstract}

\section{INTRODUCTION: BALANCING THE INDIVIDUAL RIGHT TO PRIVACY WITH LEGITIMATE LAW ENFORCEMENT SURVEILLANCE}

Horror, not humor, brought actors Michael J. Fox and Paul Reiser to testify before a hearing of the United States House Judiciary Committee last summer. ${ }^{2}$ Fox described the "mercenary tactics of tabloid photographers" who turned his wedding into a "nightmare" as helicopters recklessly jockeyed for position above the ceremony, then "fired away with high-powered cameras" on the couple's honeymoon suite. ${ }^{3}$ When Reiser's son was born prematurely, disguised journalists infiltrated the hospital with hidden cameras to steal a photo of the infant, and after returning home, the child was photographed in the privacy of the family's backyard by "resourceful" jour-

† B.A. 1991, M.P.P. Candidate 2000, University of Maryland; J.D. Candidate 2000, University of Pennsylvania. This Comment is dedicated to the memory of Alan Rubinsteingifted attomey, and the father-in-law I have known only through the many whose lives he touched. I am deeply indebted to Ed Pease, Diana Schacht, the staff and members of the U.S. House Judiciary Committee, Wendy Wiseman, and Allison Booth for the opportunity to become educated about this issue; to Professors Edwin Baker, Pamela Harris, Seth Kreimer, and David Rudovsky for their ungrudging assistance in developing the argument; to the members of the University of Pennsylvania Law Review, who are singularly responsible for transforming an extremely rough draft into the essay that follows; and especially to my wife Karen, whose continuous encouragement and support for doing what I love has led me to study the law.

${ }^{1}$ Olmstead v. United States, 277 U.S. 438, 479 (1928) (Brandeis, J., dissenting).

2 See Protection from Personal Intrusion Act \& Privacy Protection Act of 1998: Hearing on H.R. 2448 \& H.R. 3224 Before the House Comm. on the Judiciary, 105th Cong. (1998), available in Testimony Presented to Full Committee on the Judiciary (last modified May 4, 1999) <http://www.house.gov/judiciary/1.htm> [hereinafter Hearing on H.R. 2448].

${ }^{3}$ Hearing on H.R. 2448 (statement of Michael J. Fox, actor), available in 05/21/98 Committee on the Judiciary-Fox Statement (last modified May 21, 1998) <http://www. house.gov/judiciary/10142.htm>. 
nalists with telescopic lenses, and "strangers with video cameras camped outside." $" 4$

In response to the perception that such newsgathering activities have become unacceptably intrusive, legislators on both the federal and state level have devised an innovative solution to supplement existing tort liability for invasions of privacy-liability stemming from the use of "enhancement devices." Such devices include zoom lenses or high-powered microphones, which enable the observer to capture an image from distances not possible without the sophisticated surveillance technology. ${ }^{5}$ By essentially extending the common law notions of trespass, the legislative proposals would impose liability for observations that violate an individual's "reasonable expectation of privacy"6 as defined by evolving societal norms. ${ }^{7}$

Despite these worthy efforts to recognize and codify the importance of an individual right to privacy, society maintains a legitimate countervailing interest in the reasonable efficacy of law enforcement. Each legislative approach thus contains a specific exemption from liability for surveillance by state law enforcement officials. Hence, although ostensibly drafted to apply as a statute of general application to anyone who might disrespect personal privacy through the use of enhanced photography or voice recordings, ${ }^{8}$ subsections in the legislative text of both congressional bills ${ }^{9}$ and a California statute imposing liability for unwelcome enhanced surveillance ${ }^{10}$ expressly exempt law enforcement surveillance.

${ }^{4}$ Hearing on H.R. 2448 (statement of Paul Reiser, actor), available in 05/21/98 Committee on the Judiciary-Reiser Statement (last modified May 21, 1998) <http: //www.house.gov/ judiciary/10143.htm>.

5 See infra notes $97-123$ and accompanying text.

6 Katz v. United States, 389 U.S. 347,361 (1967) (Harlan, J., concurring).

${ }^{7}$ See infra notes 103,107, 111, 120 and accompanying text (noting the "expectation of privacy" element in the text of each legislative proposal).

8 By exposing any individual, rather than simply media representatives, to liability, the federal bills and a California state imposing liability for unwelcome enhanced surveillance statute seemingly avoid a determination of facial unconstitutionality based upon equal protection violations. See infra notes 107-23 for a discussion of this legislation. Nevertheless, opponents of the legislation maintain that, although not specifically applying to professional journalists, heightened liability against intrusion effectively could function as a prior restraint in violation of the First Amendment freedom of the press. See Ethan E. Litwin, Note, The Investigative Reporter's Freedom and Responsibility: Reconciling Freedom of the Press with Privacy Rights, 86 GEO. L.J. 1093, 1096 n.23 (1998) (suggesting that "a prior restraint on publication might be masquerading as a benign limitation on newsgathering").

9 See S. 2103, 105th Cong. $\S 3(\mathrm{~g})(1998)$ ("The prohibitions of this section do not apply with respect to official law enforcement activities."); H.R. 4425, 105th Cong. § 2(g) (1998) (same); infra notes 107-23 (discussing the congressional legislative proposals).

${ }^{10}$ See CAL. CIV. CODE § 1708.8(f) (West Supp. 1999).

This section shall not be construed to impair or limit any otherwise lawful activities of law enforcement personnel or employees or governmental agencies ... who, in 
What these law enforcement exemptions fail to recognize is that, pragmatically speaking, an individual's conception of what constitutes a "reasonable expectation of privacy" against police surveillance should parallel her "reasonable expectation of privacy" against observation from newsgathering activities of the media. Consequently, these legislative efforts to expand the zone of privacy with respect to intrusions from private actors, such as representatives of the media, cannot be accomplished without imposing the same restrictions on state actors engaged in law enforcement activities. Simply put, the identical test for creating liability for offensive surveillance, regardless of the affiliation of the offender, in practice must carry the same legal meaning.

This Comment argues that by invoking the precise language of the Supreme Court's Fourth Amendment "reasonable expectation of privacy" test to trigger liability, the legislative responses to overaggressive newsgathering by the paparazzi inevitably will be limited in application, or, in the alternative, will restructure and narrow the scope of permissible law enforcement surveillance activity as defined by contemporary Fourth Amendment doctrine. To that end, this Comment first provides a summary of the judicial, legislative, and constitutional efforts to codify the right of personal privacy in American law. Additionally, the discussion chronicles the tension between the individual right to privacy and the First Amendment freedom of the press. In particular, Part I of the analysis examines the various congressional proposals ${ }^{11}$ and a recently enacted California statute ${ }^{12}$ purporting to address the intrusive and aggressive newsgathering tactics of some members of the media.

Part II offers a historical discussion of Fourth Amendment jurisprudence and the scope of legitimate law enforcement surveillance that does not rise to the level of a "search," which triggers Fourth Amendment review and requirements. Specifically, the analysis examines the development of the modern judicial application of the "reasonable expectation of privacy" test to determine the presence of a Fourth Amendment search, as first articulated by Justice Harlan more than thirty years ago in the seminal case of Katz v. United States. ${ }^{13}$

the course and scope of their employment, ... attempt to capture any type of visual image, sound recording, or other physical impression of a person during an investigation, surveillance, or monitoring ....

Id.; see also infra notes 101-06 (discussing the California legislation).

${ }^{11}$ See infra notes 107-23 (discussing the congressional legislative proposals).

12 See infra notes 101-06 (discussing the California legislation).

13389 U.S. 347, 360-62 (1967) (Harlan, J., concurring). 
Finally, Part III integrates the Fourth Amendment "search" analysis with legislative efforts to expand the scope of personal privacy, illustrating the unintended consequences of either limiting the applicable scope of these legislative efforts to curb paparazzi newsgathering, or restricting permissible warrantless surveillance activity by law enforcement agents. The Comment concludes that the law enforcement exemption provisions contained in the California privacy protection law and congressional proposals fundamentally are at odds with contemporary Fourth Amendment "search" analysis. Because both the legislative text of the intrusion offense and the judicial language of the constitutional search test employ the same "reasonable expectation of privacy" element, an evolving interpretation of one necessarily must affect the judicial application of the other. In the end, these legislative attempts to sequester an expanded zone of privacy from surveillance by state officials likely will result in unintended consequences for either proponents of the legislation, or for members of law enforcement engaged in warrantless surveillance activity.

\section{THE RIGHT TO PRIVACY IN AMERICAN LAW TRADITIONS}

Over one hundred years ago, in perhaps the most renowned and cited of all law review articles, Samuel Warren and Louis Brandeis set out to establish a common law protection for the right to privacy. ${ }^{14}$ This century has witnessed volumes of literature on this subject, each creating subtle nuances and unique iterations for defining the precise scope and origin of the right. Many scholars have chosen to wax philosophical, precluding any semblance of a consensus regarding the legal nature of the right to privacy initially contemplated by Warren and Brandeis. ${ }^{15}$

In the midst of this academic debate surrounding the legal state of privacy rights, and catalyzed by recent events such as the tragic death of Princess Diana while in flight from paparazzi $\mathrm{i}^{16}$ photographers, a legislative effort is underway to promulgate and enforce laws to restrict offensive,

${ }^{14}$ See Samuel D. Warren \& Louis D. Brandeis, The Right to Privacy, 4 HARV. L. REV. 193 (1890) (discussing whether existing law afforded a principle which could be invoked to protect individual privacy).

${ }^{15}$ See Ken Gormley, One Hundred Years of Privacy, 1992 WIS. L. REV. 1335, 1339 ("Commentators have stumbled over privacy, and have failed to agree upon an acceptable definition, because they have generally focused on privacy as a philosophical or moral concept-which allows for multiplicitous definitions ...- -while wholly ignoring privacy as a legal concept.").

${ }^{16}$ The American Heritage Dictionary defines a paparazzi joumalist as a "reporter or photographer, especially a free-lance one, who doggedly searches for sensational stories about, or takes candid pictures of, celebrities for magazines and newspapers." AMERICAN HERITAGE DictionaRY OF THE ENGLISH LANGUAGE 949 (William Morris ed., 3d ed. 1981). 
intrusive newsgathering. In doing so, the legislatures-federal and stateare endeavoring to force outward the zone of personal privacy protection enjoyed by private citizens by enhancing civil and criminal liability against those engaging in offensive surveillance activities.

Since 1996, anti-paparazzi legislation has been introduced in both chambers of Congress, ${ }^{17}$ and in September, 1998, California became the first state to enact a law specifically targeting intrusive newsgathering by the media. ${ }^{18}$ The fundamental motivation behind the proposal of these statutes is a desire to protect individuals-particularly public figures such as celebrities-against intrusions of personal privacy by overaggressive paparazzi reporting and tabloid journalism.

This Part will begin by exploring the constitutional, judicial, and legislative development of privacy law, and addressing the variety of forms that the concept of privacy can take. Next, the discussion will analyze the competing interests of individual privacy rights and newsgathering activities by the media. Finally, it will examine the congressional and state legislative responses to the allegation that the press has emerged as a formidable threat to individual privacy rights ${ }^{19}$ in an age of sophisticated information technology. ${ }^{20}$

17 See H.R. 4425, 105th Cong. $\$ 1$ (1998) ("Personal Privacy Protection Act"); S. 2103, 105th Cong. $\$ 1$ (1998) (same); H.R. 3224, 105th Cong. \$ 1 (1998) ("Privacy Protection Act of 1998"); H.R. 2448, 105th Cong. $\$ 1$ (1997) ("Protection from Personal Intrusion Act").

18 See Cal. CIV. CODE $\S 1708.8$ (West Supp. 1999).

19 Regarding those in the public eye, the premonition of Warren and Brandeis in 1890 resonates with startling clarity:

The press is overstepping in every direction the obvious bounds of propriety and of decency. Gossip is no longer the resource of the idle and of the vicious, but has become a trade, which is pursued with industry as well as effrontery. To satisfy a prurient taste the details of sexual relations are spread broadcast in the columns of the daily papers.

Warren \& Brandeis, supra note 14, at 196.

${ }^{20}$ Legions of commentators have identified the proliferation of electronic communications and general technological advancements as posing the most serious threat to secured individual privacy rights. This Comment, however, is concerned narrowly with invasions of privacy in the personal intrusion, rather than informational, sense. For a sampling of the debate over technological invasions of privacy, see ANN CAVOUKIAN \& DON TAPSCOTT, WHO KNOWS: SAFEGUARDING YOUR PRIVACY IN A NETWORKED WORLD (1997), discussing the cumulative effect of new technologies on personal privacy; PRISCILLA M. REGAN, Legislating PRIVACY: TeChNOlogy, Social Values, and PUblic Policy (1995), examining various concepts and notions of privacy in public policy; GNI GRAHAM SCOTT, MIND YOUR OWN BUSINESS: THE BATTLE FOR PERSONAL PRIVACY 343-64 (1995), explaining emerging battles for privacy in the media and Congress, at trade conferences, and among lobbyists; and SYMPOSIUM, SURVEILlANCE, DATAVEILlaNCE, AND PERSONAL FREEDOMS: USE AND ABUSE OF INFORMATION TECHNOLOGY (1973), providing an overview of privacy-related problems in a technical era. See also, e.g., PATRICIA BolING, PRIVACY AND THE POLITICS OF INITMATE LIFE (1996) (providing theoretical and contemporary consid- 


\section{A. The Development of Constitutional Privacy Rights}

The United States Constitution contains no express right to privacy. Nevertheless, the medieval English common law proposition that a person's "[h]ouse is his [c]astle"21 has been incorporated as a central tenet of American legal principles since the colonial period. ${ }^{22}$ Until the late 1960 s, the Supreme Court handed down decisions grounded in these early common law origins in an attempt to strike a workable balance between an individual's personal privacy interest and society's law enforcement interest in permitting the detection of illegal activity. ${ }^{23}$ Over the last thirty years, however, the Court has begun to find a constitutionally protected right to privacy embedded in an interpretation of the First, ${ }^{24}$ Third, ${ }^{25}$ Fourth, ${ }^{26}$ Fifth, $^{27}$ and

erations for the public-private tension); DAVID F. LINOWES, PRIVACY IN AMERICA: IS YOUR PRIVATE LIFE IN THE PUBLIC EYE? (1989) (recommending fair information practices in dealings between individuals and institutions); DECKLE MCLEAN, PRVACY AND ITS INVASION (1995) (examining the history of privacy as an idea and discussing its virtues and flaws); Panel on CONFIDENTIALITY and Data ACCess, PRivate lives and PUBlic Policies: CONFIDENTIALITY AND ACCESSIBILITY OF GOVERNMENT STATISTICS (George T. Duncan et al. eds., 1993) (reviewing the availability of statistical data maintained for governmental purposes in the context of privacy considerations).

21 JOHN ADAMS, Minutes of the Review of King vs. Stewart, in 1 LEGAL PAPERS OF JOHN ADAMS 127, 137 (L. Kinvin Wroth \& Hiller B. Zobel eds., 1965).

${ }^{22}$ For extensive discussions of the early history of the "home is your castle" maxim, see DAVID H. FlaHERTY, PRIVACY IN COLONIAL NEW ENGLAND 85-88 (1972); SCOTT, supra note 20, at 43; and Gormley, supra note 15 , at $1358 \mathrm{nn} .116-19$.

${ }^{23}$ See THE PRIVACY PROTECTION STUdY COMMISSION, PERSONAL PRIVACY IN AN INFORMATION SOCIETY 346 (1977) ("The balance to be struck is an old one; it reflects the tension between individual liberty and social order. The sovereign needs information to maintain order; the individual needs to be able to protect his independence and autonomy should the sovereign overreach.").

24 See Katz v. United States, 389 U.S. 347, 350 n.5 (1967) ("The First Amendment ... imposes limitations upon governmental abridgement of 'freedom to associate and privacy in one's associations." (citations omitted)); Griswold v. Connecticut, 381 U.S. 479, 484 (1965) ("Various guarantees create zones of privacy. The right of association contained in the penumbra of the First Amendment is one ...."); see also Talley v. California, 362 U.S. 60, 64-65 (1960) (defining the right to "anonymity in public expression"); NAACP v. Alabama, 357 U.S. 449,462 (1958) (defining the right to "associational privacy"); Watkins v. United States, 354 U.S. 178, 197-98 (1957) (defining the right to "political privacy"); Sweezy v. New Hampshire, 354 U.S. 234, 250 (1957) (same).

${ }^{25}$ See Katz, 389 U.S. at 350 n.5 ("The Third Amendment's prohibition ... protects another aspect of privacy from governmental intrusion."); Griswold, 381 U.S. at 484 ("The Third amendment... prohibition against the quartering of soldiers... is another facet of . 36 privacy.").

${ }^{26}$ See Katz, 389 U.S. at 350 ("[The Fourth] Amendment protects individual privacy against certain kinds of governmental intrusion, but its protections go further, and often have nothing to do with privacy at all."); Griswold, 381 U.S. at 485 (noting that the Fourth Amendment creates a "right to privacy, no less important than any other right carefully and particularly reserved to the people."' (quoting Mapp v. Ohio, 367 U.S. 643, 656 (1961))). 
Fourteenth ${ }^{28}$ Amendments to supplement existing common law guardianship. $^{29}$ This common law and constitutional mosaic furnish the judicial bedrock of personal privacy rights today.

Since the early 1970 s, another source of privacy rights has emerged to augment the federal judicially and legislatively ensured minimums-the amendment of state constitutions to incorporate a fundamental right of personal privacy. ${ }^{30}$ As suggested by Justice Brandeis's dissenting opinion in New State Ice Co. v. Liebmann, ${ }^{31}$ expansive protection of privacy rights on a state level has emerged as the "laboratory" for "novel social and economic experiments without risk to the rest of the country."32 Following the dramatic Supreme Court decision in Katz $v$. United States, ${ }^{33}$ many states amended their constitutions to incorporate a version of the Fourth Amendment $^{34}$ regarding search and seizure, with the specific intent of securing individual privacy rights for their citizens. Beginning with Hawaii in $1968{ }^{35}$ then Illinois in $1970,{ }^{36}$ and South Carolina in $1971,{ }^{37}$ states took steps to in-

${ }^{27}$ See Katz, 389 U.S. at 350 n.5 ("To some extent, the Fifth Amendment too reflects the Constitution's concern for ... the right of each individual to a private enclave where he may lead a private life." (citations and internal quotations omitted)); Griswold, 381 U.S. at 484 ("The Fifth Amendment in its Self-Incrimination Clause enables the citizen to create a zone of privacy which government may not force him to surrender to his detriment.").

${ }^{28}$ See Wolf v. Colorado, 338 U.S. 25, $27-28$ (1949) ("The security of one's privacy against arbitrary intrusion by the police-which is at the core of the Fourth Amendment-is basic to a free society ... and as such enforceable against the states through the [Fourteenth Amendment] Due Process Clause.").

29 See Griswold, 381 U.S. at 484-86 (identifying in a plurality opinion that the "penumbras" of the Bill of Rights create a "zone of privacy" around the marital relationship into which the government may not intrude).

${ }^{30}$ For an expansive discussion charting the history and resurgence of state constitutional privacy as a reaction to deficiencies in federal legislative and judicial privacy protection, see Gormley, supra note 15, at 1420-31.

31285 U.S. 262 (1932).

${ }_{33}^{32}$ Id. at 311 (Brandeis, J., dissenting).

33389 U.S. 347 (1967); see also infra notes 175-96 and accompanying text (discussing the impact of Katz in the context of developments in Fourth Amendment "search" analysis).

${ }^{34}$ U.S. CONST. amend. IV.

The right of the people to be secure in their persons, houses, papers, and effects, against unreasonable searches and seizures, shall not be violated, and no Warrants shall issue, but upon probable cause, supported by Oath or affirmation, and particuId.

larly describing the place to be searched, and the persons or things to be seized.

${ }^{35}$ See HAW. CONST. art. I, $\S 7$ ("The right of the people to be secure in their persons, houses, papers, and effects against unreasonable searches, seizures, and invasions of privacy shall not be violated ...." (emphasis added)).

${ }^{36}$ See ILL. CONST. art. I, $\$ 6$ ("The people shall have the right to be secure in their persons, houses, papers and other possessions against unreasonable searches, seizures, invasions of privacy or interceptions of communications by eavesdropping devices or other means." (emphasis added)). 
clude "privacy" explicitly in the language of their constitutions. The "fundamental-decision privacy" ${ }^{38}$ cases of Griswold $v$. Connecticut, ${ }^{39}$ concerning contraceptive privacy rights, and Roe $v$. Wade, ${ }^{40}$ defining abortion rights, spurred constitutional amendments by Alaska, ${ }^{41}$ California, ${ }^{42}$ Montana, ${ }^{43}$ and Florida ${ }^{44}$ by the end of the $1970 \mathrm{~s}^{45}$ The Hawaii legislature also built upon its search and seizure amendment and invigorated personal privacy rights with yet another privacy amendment in $1978 .{ }^{46}$

All told, the constitutions of ten states currently contain express provisions for protecting individual privacy rights. ${ }^{47}$ Addressing the prospect of heightened state privacy rights, the Supreme Court subsequently held that the States are free to supplement the federally ensured minimums enumer-

37 See S.C. CONST. art. I, $\S 10$ ("The right of the people to be secure in their persons, houses, papers and effects against unreasonable searches and seizures and unreasonable invasions of privacy shall not be violated...." (emphasis added)).

${ }^{38}$ Gormley, supra note 15 , at 1340 . Commentators use the term "fundamental-decision privacy" to indicate a right to personal decisions that is protected by the Due Process Clause of the Fourteenth Amendment. See id. (identifying fundamental-decision privacy as among five species of legal privacy). Such privacy is distinct from those privacy rights guaranteed by the First and Fourth Amendments, state constitutions, and tort law. See id. (defining the "five dominant species of legal privacy"); Jed Rubenfeld, The Right of Privacy, 102 HARV. L. REV. 737,740 (1989) (distinguishing fundamental-decision privacy from other types of privacy).

39381 U.S. 479 (1965).

40410 U.S. 113 (1973).

41 See ALASKA CONST. art. I, $\S 22$ ("The right of the people to privacy is recognized and shall not be infringed.").

42 See CAL. CONST. art. I, § 1 ("All people are by nature free and independent and have inalienable rights. Among these are enjoying and defending life and liberty, acquiring, possessing, and protecting property, and pursuing and obtaining safety, happiness, and privacy.").

${ }^{43}$ See MONT. CONST. art. II, $\$ 10$ ("The right of individual privacy is essential to the well-being of a free society and shall not be infringed without the showing of a compelling state interest.").

44 See FLA. CONST. art. I, $\S 23$ ("Every natural person has the right to be let alone and free from governmental intrusion into his private life except as otherwise provided herein.").

45 See Mark Silverstein, Note, Privacy Rights in State Constitutions: Models for Illinois?, 1989 U. ILL. L. REV. 215, 226 (arguing that "states added express protections of privacy to their constitutions between 1968 and 1980, during a period when commentators expected that the Supreme Court's privacy/autonomy cases would continue to expand the federal protection of individual liberty").

46 See HAW. CONST. art. I, $\S 6$ ("The right of the people to privacy is recognized and shall not be infringed without the showing of a compelling state interest.").

47 The complete list of state constitutions specifically containing "privacy" or some conception of the right to be let alone in their language include: Alaska, Arizona, California, Florida, Hawaii, Illinois, Louisiana, Montana, South Carolina, and Washington. See DARIEN A. MCWHIRTER \& JON D. BIBLE, PRIVACY AS A CONSTITUTIONAL RIGHT: SEX, DRUGS, AND THE RIGHT TO LIFE 173-75 (1992) (charting the development of state constitutional privacy rights). 
ated in the Bill of Rights with respect to privacy protection. ${ }^{48}$ The Court ruled that "[i]f the state court decision indicates clearly and expressly that it is alternatively based on bona fide separate, adequate, and independent [state privacy] grounds, we, of course, will not undertake to review the decision."49 Thus, constitutional privacy rights appear to have found a "safe harbor" in the domain of the states, ${ }_{50}^{50}$ given this emergence of a "New Federalism" in the last quarter century."

\section{B. Conceptions of Privacy and Existing Remedies Against Intrusion}

Any attempt to articulate a precise definition of privacy mirrors Justice Stewart's oft-ridiculed directive for identifying obscenity-you'll 'know it when [you] see it." ${ }^{32}$ Warren and Brandeis suggested that the concept of privacy embodies "the right to be let alone." ${ }^{.53}$ Another scholar asserted that the notion of privacy is "related to solitude, secrecy, and autonomy, but is not synonymous with these terms." 54 Others have identified their conception of privacy as "a condition of inaccessibility of the person, his or her mental states, or information about the person to the senses or surveillance devices of others"; access to information about themselves"; 56 and "the claim of individuals, groups, or institutions to determine for themselves when, how, and to what extent information about them is communicated to others."

Whatever becomes of the theoretical conception of privacy in academic circles, the legal conception of privacy has unfolded through the common law into four distinct torts-intrusion upon the seclusion or solitude of an-

48 See Michigan v. Long, 463 U.S. 1032, 1040-42 (1983) (requiring only that state courts provide a "plain statement" when their decisions are based upon independent state law grounds).

${ }^{49}$ Id. at 1041.
50 Gormley, supra note 15 , at 1427.
${ }^{51} I d$. at 1422 .
${ }_{52}$ Jacobellis v. Ohio, 378 U.S. 184,197 (1964) (Stewart, J., concurring). Justice Stewart stated:

I shall not today attempt further to define the kinds of material I understand to be embraced within [the definition of obscenity] ... and perhaps I could never succeed in intelligibly doing so. But I know it when I see it, and the motion picture involved in this case is not that.

Id.

53 Warren \& Brandeis, supra note 14, at 193.

54 DAVID H. FlaherTY, PROTECTING PRIVACY IN SURVEILlANCE SOCIETIES 8 (1989).

55 ANTTA L. ALLEN, UNEASY ACCESS: PRIVACY FOR WOMEN IN A FREE SOCIETY 15 (1988).

56 Charles Fried, Privacy, 77 YALE L.J. 475, 493 (1968).

57 ALAN F. WESTIN, PRIVACY AND FREEDOM 7 (1967). 
other ("intrusion"), public disclosure of embarrassing private facts ("public disclosure"), publicity that places another in a false light ("false light"), and appropriation of another's name or likeness for one's own advantage ("appropriation"). ${ }^{58}$ Of these, journalists engaging in newsgathering activities most likely would be exposed to liability for the tort of intrusion. ${ }^{59}$ The elements of a successful claim for intrusion require that "the intrusion would be highly offensive to a reasonable person,", stitute an infringement upon "the solitude or seclusion of another or his private affairs." ${ }^{.61}$ Thus, the tort of intrusion provides a limited degree of protection against unwanted photography, such as where there is an attempt to take an unauthorized photograph within the confines of an individual's home. ${ }^{62}$ Tort law, however, generally supports the proposition that an individual in public implicitly has consented to being photographed, and thus legal remedies extend little protection to acts of intrusive photography, videotaping, or surveillance of subjects located in, or in plain view from, a public place. $^{63}$

58 See William L. Prosser, Privacy, 48 CAL. L. REv. 383, 389-407 (1960) (proposing the four-part framework for codifying tort privacy). Ultimately, this framework was adopted by the American Law Institute in its Second Restatement of Torts. See RESTATEMENT (SECOND) OF TORTS $\S 652 \mathrm{~A}-\mathrm{E}$ (1977) (setting forth the four distinct torts for privacy invasion).

59 See Litwin, supra note 8, at 1095 (noting that "the intrusion upon seclusion tort ... most directly affects journalists engaged in investigative newsgathering activities").

60 RESTATEMENT (SECOND) OF TORTS $\$ 652 \mathrm{~B}$.

${ }^{61} I d$. $\S 652 \mathrm{D}$ (creating an offense against "one who gives publicity to a matter concerning the private life of another ... if the matter publicized (a) would be highly offensive to a reasonable person, and (b) is not of legitimate concern to the public"). Comment $h$ to the section illustrates that while

the home life and daily habits of a motion picture actress may be of legitimate and reasonable interest to the public ... [t] here may be some intimate details of her life, such as sexual relations, which even the actress is entitled to keep to herself.... The limitations ... are those of common decency. Id. cmt. h.

62 See, e.g., Phillip E. Hassman, Annotation, Taking Unauthorized Photographs as Invasion of Privacy, 86 A.L.R.3d 374, 376 (1978).

When a picture is taken of a plaintiff while he is in the privacy of his home ..., the taking of the picture may be considered an intrusion into the plaintiffs privacy ..... Of course, the courts have no trouble finding an invasion of privacy when the photographer actually enters the plaintiff's home by subterfuge, or without consent, to Id. take a photograph.

${ }^{63}$ See Hartman v. Meredith Corp., 638 F. Supp. 1015, 1018 (D. Kan. 1986) ("The plaintiffs must show that there has been some aspect of their private affairs which has been intruded upon and does not apply to matters which occur in a public place or place otherwise open to the public eye."); Fogel v. Forbes, Inc., 500 F. Supp. 1081, 1087 (E.D. Pa. 1980) ("[T]his tort does not apply to matters which occur in a public place or a place otherwise open to the public eye."); see also Hassman, supra note 62, at 375 ("Where the picture is taken on the public streets, or in a public place such as a courtroom or a sporting event, the courts have 
Other remedies currently are available under statutory and common law. Several states, including California and New York, have existing laws to prohibit harassment and enable individuals to obtain injunctive relief from press hounding. ${ }^{64}$ Theories of harassment even can rise to the level of intrusion, thus warranting indirect protection for violations of privacy, including offenses that occur in public settings. ${ }^{65}$ The most noted paparazzi/privacy case involved former First Lady Jacqueline Kennedy Onassis, who was granted an injunction against freelance celebrity photographer and self-described paparazzo Ron Galella. ${ }^{66}$ An injunction also was issued against reporters who were gathering information for a story by engaging in such aggressive techniques as following the plaintiffs' children to school, videotaping their home, and using a shotgun microphone ${ }^{67}$ to record the plaintiffs' conversations while within the privacy of their home. ${ }^{68}$

Alternative common law and statutory remedies include stalking or shadowing laws, which traditionally have been applied to the surveillance activities of private investigators. ${ }^{69}$ In addition, the press can be held liable

refused to consider the taking as an invasion of privacy."); Andrew Jay McClurg, Bringing Privacy Law out of the Closet: A Tort Theory of Liability for Intrusions in Public Places, 73 N.C. L. REV. 989, 991 (1995) ("As interpreted by almost all courts, the tort [of intrusion] does not protect persons in places accessible to the public.").

64 California defines harassment as "a knowing and willful course of conduct directed at a specific person which seriously alarms, annoys, or harasses a person, and which serves no legitimate purpose." CAL. CIV. PROC. CODE $§ 527.6(\mathrm{~b})$ (West 1999). It is unclear whether newsgathering activities would fall within the statutory exception for "legitimate purpose." Id. New York's statute provides a remedy for harassment when there is an "intent to harass, annoy, or alarm another person" and "follow a person in or about a public place." N.Y. PENAL LAW § 240.26 (McKinney 1998).

${ }^{65}$ See Galella v. Onassis, 487 F.2d 986, 999 (1973) (affirming the district court's injunction under the New York harassment provisions against a paparazzi photographer working in a public setting).

${ }^{66}$ See id. (finding the photographer's actions offensive and upholding the lower court's injunction).

67 The Supreme Court described a shotgun microphone or "spike mike" as "a microphone with a spike about a foot long attached to it, together with an amplifier, a power pack, and earphones." Silverman v. United States, 365 U.S. 505, 506 (1961). For a discussion of this case, see infra notes 153-58 and accompanying text.

68 See, e.g., Wolfson v. Lewis, 924 F. Supp. 1413, 1435 (E.D. Pa. 1996) (granting a preliminary injunction to prevent reporters from placing an individual's home under surveillance).

${ }^{69}$ Shadowing and stalking laws are primarily concerned with cases in which a person being watched, shadowed, or trailed has filed a personal injury suit against another who hired a private detective to investigate the validity of a claim against the plaintiff. See, e.g., Munson v. Milwaukee Bd. of Sch. Dirs., 969 F.2d 266, 268 (7th Cir. 1992) (holding that the plaintiff's privacy rights were not violated when the defendant shadowed him for the purpose of determining his compliance with school employee residency requirements); Johnson v. Corporate Special Servs., Inc., 602 So. 2d 385, 388 (Ala. 1992) (finding no invasion of privacy where detectives investigated a worker's compensation claim against the plaintiff, because the plain- 
for false imprisonment if the targets of the newsgathering activity physically are prevented from carrying out their intended courses of action. ${ }^{70}$ In a notable recent case, two photographers drove Arnold Schwarzenegger and his wife, Maria Shriver, off the road after "swarm[ing]" around the Schwarzeneggers' car in order to take the first photographs of the actor following his hospital release after elective heart surgery. ${ }^{71}$ Both photographers were found guilty of false imprisonment; one was sentenced to sixty days and the other to ninety days in prison. ${ }^{72}$ The final alternative remedy for privacy intrusions provides that the media can be charged with a trespass violation where there is an unlawful physical entrance on private property. ${ }^{73}$ These statutes, however, generally target the persistent following and chasing by the paparazzi, rather than the intrusive photography and recording activities that the recent California law and congressional proposals are intended to thwart. $^{74}$

\section{Privacy and the Press: Competing First Amendment Claims}

[W]ithout some protection for seeking out the news, freedom of the press could be eviscerated. ${ }^{75}$

[G]enerally applicable laws do not offend the First Amendment simply because their enforcement against the press has incidental effects on its ability to gather and report the news.... [T] he truthful information sought to be published must have been lawfully acquired. ${ }^{76}$

tiff "should have expected a reasonable amount of investigation into his physical incapability").

${ }^{70}$ See News Lite Pictures Worth Jail Time for Two, L.A. DAIY NEwS, Feb. 24, 1998, at N2, available in 1998 WL 3851746 (noting that the Superior Court judge believed that "the photographers had created a dangerous situation" because "[a]ny type of car chase is simply life-threatening to those involved").

${ }^{71} \mathrm{Id}$.

72 See id.

73 See, e.g., CAL. PENAL CODE $\S 602.5$ (West Supp. 1998) (characterizing entry onto private property without the consent of the owner as a misdemeanor); N.Y. PENAL LAW $\S \S 140.5,140.10,140.15$ (McKinney Supp. 1998) (defining criminal trespass).

${ }^{74}$ The debate over curbing the paparazzi has spawned two tracks of proposed legislative responses: the tort of "constructive trespass," see CAL. PENAL CODE $\S 1708.8$ (West Supp. 1998); H.R. 4425, 105th Cong. (1997); S. 2103, 105th Cong. (1997), and the tort of "harassment for commercial purposes," see H.R. 2448, 105th Cong. (1997); H.R. 3224, 105th Cong. (1997); H.R. 4425, 105th Cong. (1997); S. 2103, 105th Cong. (1997). See infra Part I.D (discussing the scope of anti-paparazzi legislation).

${ }_{75}$ Branzburg v. Hayes, 408 U.S. 665, 681 (1972).

76 Cohen v. Cowles Media Co., 501 U.S. 663, 669 (1991). 
The First Amendment prohibits Congress from abridging the freedom of the press, but this freedom is not absolute. ${ }^{77}$ Given the importance of individual privacy rights, "the First Amendment does not protect journalists from liability for intruding, whether by physical or electronic means, into the seclusion of another while gathering news."78 There is a distinction to be drawn between legitimate newsgathering on the one hand, and unprotected, tortious conduct by the media on the other. ${ }^{79}$ Although the First Amendment protections routinely provide a powerful shield against liability for publication, ${ }^{80}$ these protections have "never been construed to accord newsmen immunity from torts or crimes committed during the course of newsgathering." ${ }^{, 81}$ It thus is clear that the First Amendment should not be construed as "a license to trespass, to steal, or to intrude by electronic means into the precincts of another's home or office.,82

Nonetheless, a photographer's ability to take pictures in large part depends upon the freedom to access places where the subject is located. In many respects, the "right to gather information is logically antecedent and practically necessary to any effective exercise of [the right to publish, which] ... cannot be given full meaning unless that antecedent right is recognized." ${ }^{.83}$ As such, "liability for intrusion is not absolute, but is subject to the limitation that the intrusion be highly offensive to a reasonable person. ${ }^{, 84}$ In the seminal case of New York Times Co. v. Sullivan, ${ }^{85}$ the Supreme Court recognized that the First Amendment protections must afford, to some extent, a degree of protection for information gathering as well as dissemination in order to prevent a chilling effect on investigative journalism. $^{86}$

77 See id.

78 Edward L. Raymond, Jr., Annotation, Intrusion by News-Gathering Entity as Invasion of Privacy, 69 A.L.R.4th 1059, 1065-66 (1990).

79 See Zemel v. Rusk, 381 U.S. 1, 17 (1965) ("The right to speak and publish does not carry with it the unrestrained right to gather information.").

${ }^{80}$ See infra notes 114-16 and accompanying text (distinguishing newsgathering activities from the subsequent dissemination of captured images and recordings).

81 Dietemann v. Time, Inc., 449 F.2d 245, 249 (9th Cir. 1971).

${ }^{82} I d$.

83 Note, The Right of the Press to Gather Information, 71 COLUM. L. REV. 838, 843 (1971).

${ }^{84}$ Raymond, supra note 78, at 1065.

85 376 U.S. 254, 264-65 (1964).

${ }^{86}$ See id. at 279 (holding that a rule permitting libel judgments against newsgatherers would "lead[] to a comparable self-censorship"); see also Jane E. Kirtley, Vanity and Vexation: Shifting the Focus to Media Conduct, 4 WM. \& MARY BILL OF RTS. J. 1069, 1099-1106 (1996) (citing as an example of the chilling effect on journalism the decision by CBS not to broadcast an interview with a corporate whistleblower out of fear of potential tort liability for interfering with a contractual relationship). 
Two differing approaches have developed for Supreme Court review of First Amendment free speech claims. ${ }^{87}$ Where the "communicative impact" of speech is implicated, the regulations presumptively are unconstitutional, such as where a particular idea or viewpoint is singled out for analysis. ${ }^{88}$ These regulations are subject to the burden of showing either that they apply only to unprotected speech, ${ }^{89}$ or are narrowly constructed to further a compelling state interest. ${ }^{90}$ Where only the "non-communicative impact" of speech is jeopardized, resulting in an indirect restriction on free speech, the Court applies an ad hoc balancing test, weighing "the extent to which communicative activity is in fact inhibited... [in light of] the values, interests, or rights served by enforcing the inhibition." 91 Thus, any attempt to expand the right of personal privacy at the expense of respecting the freedom of the press should be constitutionally suspect and subject to careful judicial scrutiny. ${ }^{92}$

\section{Anti-Paparazzi Statutes: The Legislature Answers Back}

Unsatisfied at times with the strength and scope of privacy right protection provided by the courts, the federal and state legislatures often have intervened to establish and fortify areas of personal privacy protection from intrusions by both state and private actors. ${ }^{93}$ While constitutional limitations relegate the courts to the defensive posture of resolving only the

${ }^{87}$ See LAURENCE H. TRIBE, AMERICAN CONSTITUTIONAL LAW $\S 12-2$, at 791 (2d ed. 1988) (describing two paths for analyzing abridgements of speech).

88 See id. (defining viewpoint discrimination).

89 See Chaplinsky v. New Hampshire, 315 U.S. 568, 572 (1942) (defining categories of speech that are not subject to the protections of the First Amendment because they do not provide an "essential part of any exposition of ideas").

${ }^{90}$ See TRIBE, supra note $87, \S 12-8$, at 833 (describing the compelling state interest requirement).

91 Id. \$12-23, at 979 .

92 See Note, Privacy, Photography, and the Press, 111 HARV. L. REV. 1086, 1086 (1998) (arguing that "although photographers should not be exempt from generally applicable laws, laws that target photography for regulation, whether facially or in practical effect, should be subject to strict judicial scrutiny").

93 For example, the tragic death of Princess Diana has spawned a litany of congressional and state legislative proposals to reign in paparazzi newsgathering tactics. See infra notes 101-34 and accompanying text (detailing federal and state anti-paparazzi proposals). In addition, congressional action in the wake of the Watergate scandal led to the passage of the first national privacy protection statute-The Privacy Act of 1974, Pub. L. No. 93-579, § 2, 88 Stat. 1896 (1974), granting an individual the right of access to information collected and used by federal agencies. For an overview of this legislation, see Matthew N. Kleiman, Comment, The Right to Financial Privacy Versus Computerized Law Enforcement: A New Fight in an Old Battle, 86 Nw. U. L. REV. 1169, 1183-85 (1992), discussing the scope and application of the Privacy Act of 1974. 
"Cases" and "Controversies" that present themselves, ${ }^{94}$ the legislatures have moved aggressively to address deficiencies in privacy law found contrary to the public interest. ${ }^{95}$ In fact, of the myriad of privacy statutes in force today, many are "derived from legislative dissatisfaction with the results or pace of the judiciary's protection of privacy. 96

On the heels of the Princess Diana tragedy, ${ }^{97}$ and fueled more recently by the perceived intrusive nature of the coverage of the Clinton-Lewinsky matter, ${ }^{98}$ legislators have introduced a series of proposals to "deter those who would intrude upon [a citizen's] most private moments."999 Believing that existing common law and statutory remedies provide insufficient protection, legislatures at both the federal and state levels have moved to carve out greater protection for personal privacy rights. ${ }^{100}$

In September 1998, then California Governor Pete Wilson signed into law a new section of the state's Civil Code providing a statutory claim for the common law tort of invasion of privacy. ${ }^{101}$ To bring a successful claim under the provision, a plaintiff must demonstrate that the person seeking to capture an image or sound recording has either: (1) knowingly committed an act of trespass in order to capture the image or sound recording, ${ }^{102}$ or (2)

94 U.S. CONST. art. III, $\S 2$ (enumerating the jurisdiction of federal courts).

95 See REGAN, supra note 20, at 5-10 (summarizing congressional activity since 1974 in the area of privacy protection); Kleiman, supra note 93 , at 1170-72 (discussing the role of the legislature in preserving personal privacy).

96 Kleiman, supra note 93, at 1170.

97 See Howard Kurtz, Public to Press: Just Play Fair; They're Peeved by Intrusiveness and Deception. But Are New Laws the Answer?, WASH. POST, Sept. 15, 1997, at B4, available in LEXIS, News Library, Curnws File (describing public anger at perceived media excesses and the various legislative responses).

${ }^{98}$ See William Claiborne, L.A. Police Warn News Media About Pursuit of Lewinsky, WASH. POST, Feb. 8, 1998, at A1 (documenting the "virtual siege by news photographers and television camera operators camped outside [the Lewinsky] home" since Lewinsky's allegations against President Clinton were made public).

99 Press Release, Screen Actors Guild, Screen Actors Guild Hails Passage of California Privacy Law (Sept. 30, 1998).

${ }^{100}$ See S. 2103, 105th Cong. $§ 2(a)(5)$ (1998) ("[T]echnological advances such as telephoto lenses and hyperbolic microphones render inadequate existing common law and State and local regulation of such trespass and invasion of privacy."); ASSEMBLY COMM. ON THE JUDICIARY, REP. ON S.B. 262, 1997-98 Reg. Sess. (Cal. 1998) ("Although some [paparazzi] behavior already constitutes common law torts or criminal activity ...., the damages [allowed under current law] are de minimis, so there is no deterrent value to suit." (internal quotations omitted)).

${ }_{102}$ See CAL. CIVIL CODE $\S 1708.8$ (West 1998) (creating the tort of invasion of privacy).

A person is liable for physical invasion of privacy when the defendant knowingly enters onto the land of another without permission or otherwise committed a trespass, in order to physically invade the privacy of the plaintiff with the intent to capture any type of visual image, sound recording, or other physical impression of the 
committed a "constructive invasion of privacy" by attempting to capture an image or sound recording through the use of an enhancement device, where the victim had a "reasonable expectation of privacy," and an actual trespass would have been necessary without the use of the enhancement device. ${ }^{103}$ Remedies for a violation include treble ${ }^{104}$ and punitive damages, plus disgorgement of any proceeds or other consideration obtained as a result of the commercial use of the images or recordings captured. ${ }^{105}$ The section also provides for the vicarious liability of any person who "directs, solicits, actually induces, or actually causes another person [to commit an act of trespass or constructive trespass,] . . regardless of whether there is an employeremployee relationship." 106

Discontented with the narrow application of state legislative protection, and stressing the national scope of the problem, proponents of stricter privacy protection turned their attention to Congress to enact a federal solution. In the Senate, Judiciary Committee Chairman Orrin Hatch (R-Utah), joined by Senator Dianne Feinstein (D-Cal.), announced new legislation designed to create enhanced civil and criminal penalties for intrusive newsgathering activities. $^{107}$ Entitled the "Personal Privacy Protection Act,"108 the legisla-

plaintiff engaging in a personal or familial activity and the physical invasion occurs in a manner that is offensive to a reasonable person.

Id. $\$ 1708.8(\mathrm{a})$.

103

A person is liable for constructive invasion of privacy when the defendant attempts to capture, in a manner that is offensive to a reasonable person, any type of visual image, sound recording, or other physical impression of the plaintiff engaging in a personal or familial activity under circumstances in which the plaintiff had a reasonable expectation of privacy, through the use of a visual or auditory enhancing device, regardless of whether there is a physical trespass, if this image, sound recording, or other physical impression could not have been achieved without a trespass unless the visual or auditory enhancing device was used.

Id. $\$ 1708.8(\mathrm{~b})$.

104 Treble damages consist of "the single damages found by the jury, actually tripled in amount." BLACK's LAW DICTIONARY 3936 (6th ed. 1990).

${ }^{105}$ See CAL. CIV. CODE $\S 1708.8$ (c) (detailing financial liability under the law).

106 Id. $\S 1708.8(\mathrm{~d})$.

107 See S. 2103, 105th Cong. $\$ 4(\mathrm{~b})(2)(\mathrm{A})(1998)$ (proposing a cause of action that mirrors the California statute, including the requirement that the subject have a "reasonable expectation of privacy with respect to the personal or familial activity captured").

108 The proposed legislation also includes a "harassment" provision which would impose liability whenever a person "persistently physically follows or chases a person in a manner that causes the person to have a reasonable fear of bodily injury, in order to capture by a visual or auditory recording instrument any type of visual image, sound recording, or other physical impression of the person" and the image or recording is captured "for commercial purposes." Id. §3(a)(2); see also H.R. 4425, 105th Cong. § 2(a)-(b) (1998) (providing protection from personal intrusion for commercial purposes by adding a reckless endangerment and tortious invasion of privacy cause of action to the United States Code); H.R. 3224, 105th 
tion includes the finding that the "legitimate privacy interests of individuals and their families have been violated"109 by media agents who commonly use "intrusive modern visual or auditory enhancement devices, such as powerful telephoto lenses and hyperbolic microphones that enable invasion of private areas that otherwise would be impossible without trespassing.",110 Like the California enactment, an element of the offense requires that the subject of the newsgathering activity have "a reasonable expectation of privacy with respect to the personal or familial activity captured."111

Congressional jurisdiction to address the situation derives from the Commerce Clause. ${ }^{112}$ The proposed legislation would apply only when the visual image or recording is: (1) found to have been, or was intended to have been, captured for a commercial purpose and (2) sold, published, or transmitted in interstate commerce. ${ }^{113}$ Jurisdiction also would be established whenever the person capturing the image or recording herself moved in interstate commerce in order to capture the physical impression. ${ }^{114}$ Note, however, that although the proposal contains a commercial purpose requirement for jurisdictional reasons, no liability applies for activity involving "the sale, transmission, publication, broadcast, or use of any image or recording of the type or under the circumstances described herein in any otherwise lawful manner."

Cong. $\S 2$ (a) (1998) (providing protection from personal intrusion for commercial purposes by creating a harassment standard); H.R. 2448, 105th Cong. $\$ 2$ (a) (1997) (providing a cause of action against harassment). This aspect of the legislation falls beyond the scope of this Comment, but for a discussion of the "harassment" provisions in recent legislative proposals, see Dennis F. Hemandez, Current Developments in Privacy Litigation, 523 PLI/PAT 263, 293-95 (1998), analyzing the Federal Personal Privacy Protection Act and related California and Utah regulations; Victor A. Kovner et al., Recent Developments in Newsgathering, Invasion of Privacy and Related Torts, 498 PLI/PAT 539, $554-58$ (1997), discussing claims against paparazzi intrusions and uninvited ride-alongs, where a camera or other recording device captures images without the subject's permission; Note, supra note 92, at 1090-91, discussing the legislative history of the California Personal Intrusion Act.

${ }^{109}$ S. 2103, 105th Cong. § 2(a)(2).

$110 \mathrm{Id}$.

111 Id. § 4(b)(2)(a).

112 See U.S. CONST. art. I, \& 8 ("The Congress shall have Power ... To regulate Commerce with foreign nations, and among the several states.").

113 See S. 2103, 105th Cong. $\$ 4(\mathrm{a})(2)$ ("[A] visual image, sound recording, or other physical impression shall not be found to have been, or intended to have been, captured for commercial purposes unless it was intended to be, or was in fact, sold, published, or transmitted in interstate or foreign commerce....").

114 See id. (providing that an image, sound recording, or other physical impression will be considered commercial where "the person attempting to capture such image, recording, or impression moved in interstate or foreign commerce in order to capture such image, recording, or impression").

115 Id. $\S 4(\mathrm{e})$. 
tured, irrespective of the manner in which it is obtained, the First Amendment provides effective refuge against civil or criminal liability for its subsequent treatment, ${ }^{116}$ subject to existing common law torts such as public disclosure, false light, or appropriation. ${ }^{117}$

In the House of Representatives, a companion bill to the Senate measure also was introduced during the 105th Congress. ${ }^{118}$ Sponsored by John Conyers (D-Mich.) and Bill McCullom (R-Fla.), the House proposal creates the offense of "tortious invasion of the privacy of another person" $" 119$ whenever an image or sound recording is: (1) captured using an enhancement device, (2) the subject possesses "a reasonable expectation of privacy,"120 and (3) the "impression could not have been captured without a trespass if not produced by the use of the enhancement device."121 This bill, like the Senate version, is careful to distinguish between the intrusive newsgathering activities targeted, and the sale, transmission, publication, or broadcast of the images, ${ }^{122}$ which is specifically exempted from both civil and criminal liability due to First Amendment concerns. ${ }^{123}$

In an attempt to prevent deleterious effects on law enforcement, however, the federal and state legislative efforts contain a specific exemption for surveillance activity by state actors. ${ }^{124}$ The legislative history accompany-

116 See, e.g., In re King World Productions, Inc., 898 F.2d 56, 59-60 (6th Cir. 1990) (criticizing a television news magazine for surreptitiously videotaping the plaintiff, but vacating a temporary restraining order preventing broadcast of the videotape); see also RAYMOND WACKS, PRIVACY AND PRESS FREEDOM 142 (1995) (asserting that "the intrusive activity by which ... information is obtained must be treated distinctly from its subsequent disclosure").

117 See supra note 58 and accompanying text (discussing Dean Prosser's four-part framework for enforcing tort privacy).

118 Two additional anti-paparazzi bills were introduced during the 105th Congress, by Representatives Sonny Bono (R-Cal.) and Elton Gallegly (R-Cal.), but they proposed a cause of action only against harassment and not against trespass or constructive trespass. See H.R. 3224, 105th Cong. (1998); H.R. 2448, 105th Cong. (1997); supra note 108 (discussing alternative versions of House acts that provide protection from personal intrusions for commercial purposes).

\footnotetext{
119 H.R. 4425, 105th Cong. $\$ 2$ (b) (1998).

120 Id. $\$ 2(\mathrm{c})(2)(\mathrm{A})(\mathrm{i})$.

121 Id. $\S 2(\mathrm{c})(2)(\mathrm{A})(\mathrm{ii})$.
}

122 See id. \& 2(e) ("Nothing in this section makes the sale, transmission, publication, broadcast, or use of any image or recording of the type or under the circumstances described in this section in any otherwise lawful manner by any person subject to criminal charge or civil liability."); see also S. 2103, 105th Cong. § 4(f) (1998) (same).

123 Commentators proposing remedies for the intrusive newsgathering activities of the press bifurcate their legal analysis to distinguish between the process of gathering the information and the information's subsequent publication. See supra notes 112-16 and accompanying text ("[T]he First Amendment provides effective refuge against civil or criminal liability for its subsequent treatment ....").

${ }^{124}$ See supra notes 9-10 and accompanying text. 
ing the California statute, for example, states that "[a]ppropriately, [the law] specifically excludes from its ambit legitimate law enforcement or other governmental agency activities." 25 This is the case although contemporary Fourth Amendment doctrine triggers constitutional scrutiny for warrantless search activities by a public official using the very same test as the intrusion legislation-whether the observation has encroached upon an individual's "reasonable expectation of privacy." Thus, taken in their entirety, the California law and congressional proposals represent a legislative attempt to thrust outward the scope of personal privacy vis-à-vis private actors, while simultaneously resisting a broadening of this protection with respect to surveillance at the hands of the state.

These congressional and state responses predictably have come under attack from a broad range of free press advocates, including the RadioTelevision News Directors Association, ${ }^{126}$ the National Press Photographers Association, ${ }^{127}$ and the American Society of Newspaper Editors. ${ }^{128}$ Critics assert that enacting laws to regulate the news media "would be unnecessary, unwise, and unconstitutional,"129 and could produce "a deleterious effect ... on the newsgathering process. ${ }^{.130}$ In their view, First Amendment free press rights to some degree must trump personal privacy expectations if the media effectively is to serve the public interest. In the words of one court, the "legitimate countervailing social needs may warrant some intrusion despite an individual's reasonable expectation of privacy and freedom from harassment."131 Furthermore, the common law now recognizes that "public figures have to some extent lost the right of privacy, and it is proper to go further in dealing with their lives and public activities than with those of entirely private persons." ${ }^{\text {"132 }}$ Moreover, within the domain of protection

125 ASSEMBLY COMM. ON THE JUdICIARY, REP. ON S.B. 262, 1997-98 Reg. Sess. (Cal. 1998).

${ }_{26}$ See Hearing on H.R. 2448, supra note 2 (statement of Barbara S. Cochran, President, Radio-Television News Directors Association) ("Any attempt to regulate those who engage in newsgathering raises compelling First Amendment concems.").

${ }_{127}$ See id. (statement of David R. Lutman, President, National Press Photographers Association) (stating that the "primary effect [of anti-paparazzi legislation] ... will be to greatly reduce the legitimate news gathering activities of journalists who obey the law").

${ }^{128}$ See id. (statement of Paul C. Tash, Executive Editor, St. Petersburg Times, on behalf of the American Society of Newspaper Editors) ("This bill is unnecessary, and it reaches way beyond the ultimately narrow problem it purports to address."). Forum).

${ }^{129}$ Id. (statement of Paul K. McMasters, First Amendment Ombudsman, The Freedom

${ }^{130}$ Id. (statement of Robert D. Richards, Founding Director, Pennsylvania Center for the First Amendment).

${ }^{131}$ Galella v. Onassis, 487 F.2d 986, 995 (2d Cir. 1973).

132 Carlisle v. Fawcett Publications, Inc., 201 Cal. App. 2d 733, $746-47$ (Ct. App. 1962) (" $[\mathrm{T}]$ here is a public interest which attaches to people who by their accomplishments, mode of 
against surveillance, which can come at the hands of private as well as state actors, opponents of strengthened personal privacy laws invoke First Amendment free speech protections to support their position. ${ }^{133}$

Notably, each of these legislative proposals, congressional and state, invokes some form of the "reasonable expectation of privacy" test as an element of the offense. ${ }^{134}$ The derivation and significance of this required element is the focus of the next two Sections.

\section{THE SCOPE OF PERMISSIBLE LAW ENFORCEMENT SURVEILLANCE ${ }^{135}$}

\section{A. Emergence of the Trespass Standard}

The early battles pitting the rights of personal privacy against law enforcement surveillance emerged in the domain of wiretapping activity at the time of Prohibition. ${ }^{136}$ In the landmark case of Olmstead $v$. United States, ${ }^{137}$ the Supreme Court determined whether evidence obtained through the monitoring of the defendants' telephone calls contravened the Fourth Amendment restriction on conducting warrantless searches. ${ }^{138}$ The defen-

living, professional standing or calling, create a legitimate and widespread attention to their activities.").

${ }^{133}$ See Gormley, supra note 15, at 1374-91. One must be careful to distinguish between these two types-free speech and free press-of First Amendment privacy rights. See id. at 1375. In the case of free speech, this privacy is merely parasitic, "deriving its importance not from any direct or consistent source in the Constitution, but as a counterweight ... . in order to restrict[ free speech under the Constitution." Id. Thus, the privacy right in question has developed not as an independent fundamental right, as is the case with the right to privacy against unreasonable search and seizure, but as a counterweight to mitigate abuses of freedom of speech. For example, this right to privacy may act to constrain an assertion of free speech by a religious solicitor who wanders door-to-door in a residential neighborhood. See id. On the other hand, collisions with freedom of the press "involve privacy as a mere tort ... enjoy[ing] no preferred status in the law." Id.

${ }^{134}$ See supra notes 103, 111, 121 and accompanying text (detailing the specific textual language in each proposed regulation).

${ }^{135}$ For a thorough review of the status and history of Fourth Amendment analysis, see Leslie A. Maria, Overview of the Fourth Amendment, 86 GEO. L.J. 1187 (1998).

${ }^{136}$ Some commentators argue that the first in-depth analysis of the Fourth Amendment by the Supreme Court occurred earlier, in the landmark case of Boyd v. United States, 116 U.S. 616 (1886). In that case, "the Court created a hierarchy of personal property rights, with the permissibility of a search or seizure premised on whether the government had a superior interest in the thing to be searched or seized." Thomas K. Clancy, What Does the Fourth Amendment Protect: Property, Privacy, or Security?, 33 WAKE FOREST L. REV. 307, 312 (1998). For a general discussion of the case and emergent framework, see id. at 312-16.

137277 U.S. 438 (1928), rev'd on other grounds by Berger v. New York, 388 U.S. 41 (1967).

${ }^{138}$ See Olmstead, 277 U.S. at 455 (addressing "the single question whether the use of evidence of private telephone conversations between the defendants and others, intercepted by means of wire tapping, amounted to a violation of the Fourth ... . Amendment $\square$ '). 
dants were convicted of a conspiracy to violate the National Prohibition Act, ${ }^{139}$ and appealed on the grounds that the prosecution's case relied nearly exclusively on evidence gathered through a wiretap of the defendants' telephone lines in violation of their right to privacy embedded in the Fourth Amendment. ${ }^{140}$ In holding that the government's conduct did not impugn the defendants' constitutional protections, the Court reasoned that the intent of the Fourth Amendment strictly was to guard against searches of a physical nature. ${ }^{141}$ Since the state agents inserted the wires from the basement of an office building located on a public street and never entered the defendants' property, ${ }^{142}$ Chief Justice Taft found no textual support for invoking the protection of the Fourth Amendment. ${ }^{143}$

In a portentous dissent that would prove to represent the modern incarnation of search and seizure jurisprudence, Justice Brandeis vehemently objected to such a construction of the Fourth Amendment. ${ }^{144}$ In his view, the Founders crafted the language of the Fourth Amendment in response to "an experience of evils"145 that did not include or even contemplate the development of telephones and electronic surveillance technology. ${ }^{146}$ Furthermore, just as the Founders could not have predicted the sophistication of information gathering techniques to come in future generations, Brandeis was deeply troubled, not only by the presence of "what has been,"147 but by the possibility "of what may be." 148

139 See id. (stating that the petitioners were convicted of a conspiracy by "unlawfully possessing, transporting and importing intoxicating liquors and maintaining nuisances, and by selling intoxicating liquors").

${ }^{140}$ See id. at 482 ("The [wiretap] evidence ... . constitutes the warp and woof of the government's case. ... There is literally no other evidence of guilt on the part of some of the defendants except that illegally obtained by these officers.").

${ }^{141}$ See id. at 464 (noting that the language of the Fourth Amendment suggests that "the search is to be of material things - the person, the house, his papers or his effects").

142 See id. at 457 ("The insertions were made without trespass upon any property of the defendants. They were made in the basement of a large office building.").

${ }^{143}$ See id. at 464 ("The Amendment does not forbid what was done here. There was no searching. There was no seizure. The evidence was secured by the use of the sense of hearing and that only. There was no entry of the houses or offices of the defendants.").

144 See id. at 471-85 (Brandeis, J., dissenting).

145 Id. at 472 (Brandeis, J., dissenting).

146 See id. at 472-73 (Brandeis, J., dissenting) ("Clauses guaranteeing to the individual protection against specific abuses of power, must have a ... capacity of adaptation to a changing world .... [T]ime works changes, brings into existence new conditions and purposes." (internal quotations omitted)).

${ }^{147}$ Id. at 475-76 (Brandeis, J., dissenting) ("Whenever a telephone line is tapped, the privacy of the persons at both ends of the line is invaded, and all conversations between them upon any subject, and although proper, confidential and privileged, may be overheard.").

${ }^{148}$ Id. at 474 (Brandeis, J., dissenting) ("The progress of science in furnishing the government with means of espionage is not likely to stop with wire-tapping. Ways may some day 
Over the following several decades, the Supreme Court adhered to Olmstead's conclusion that no search or seizure occurs in the absence of a physical trespass. In Goldman v. United States, ${ }^{149}$ the Court held that federal agents acted within constitutional guidelines when planting a dictaphone recording device in a partition wall to listen in on conversations taking place inside the next room, and the opinion expressly reaffirmed the Olmstead holding. ${ }^{150}$ In On Lee $v$. United States, an undercover agent wearing a concealed microphone entered a retail store to investigate narcotics violations while another agent listened in from a location outside the building. ${ }^{151}$ No constitutional violation was found, since the use of electronic equipment substantially resembled the permissible use of bifocals, field glasses, or telescopes. ${ }^{152}$ It was not until the late 1960s, in the case of Silvernan $v$. United States, ${ }^{153}$ where the Court found evidence of an actual trespass by law enforcement agents, that surveillance activity invading the defendant's physical space was declared to be a violation of the Fourth Amendment. ${ }^{154}$ In Silverman, police officers used a directional microphone, or "spike mike,"155 to tap into a heating duct of a row house to eavesdrop on conversations taking place inside. ${ }^{156}$ The majority opinion by Justice Stewart determined that the microphone's placement in contact with the heating duct created "the reality of an actual intrusion into a constitutionally protected area."157 Thus, the majority was able to conclude that the constitutional protections against unreasonable searches had been violated while continuing to adhere to a view that evidence of a physical trespass is a necessary condition for triggering Fourth Amendment scrutiny. ${ }^{158}$

be developed by which the Government ... will be enabled to expose to a jury the most intimate occurrences of the home.").

149316 U.S. 129 (1942), overruled in part by Katz v. United States, 389 U.S. 347 (1967).

150 See id. at 135 (dismissing the defendant's argument that when "one talks in his own office, and intends his conversation to be confined within the four walls of the room, he does not intend his voice shall go beyond these walls" and holding that "no reasonable or logical distinction can be drawn between what federal agents did in the present case and state officers did in the Olmstead case").

151343 U.S. 747 (1952).

152 See id. at 754 (noting that "[t]he use of bifocals, field glasses or the telescope to magnify the object of a witness' vision is not a forbidden search or seizure").

153365 U.S. 505 (1961).

154 See id. at 511 (finding the search unconstitutional because "the officers overheard the [defendants'] conversations only by usurping part of [their] house or office").

155 See supra note 67 (noting the Supreme Court's definition of a "spike mike").

156 See Silverman, 365 U.S. at 506 ("The record clearly indicates that the spike made contact with a heating duct serving the house ....").

157 Id. at 512.

158 See id. ("We find no occasion to re-examine Goldman here, but we decline to go beyond it, by even a fraction of an inch."). 


\section{B. Brandeis Vindicated: The Court Adopts a Privacy Standard}

While the Silverman Court refused to abandon the conception of Fourth Amendment privacy being related to the property law conception of trespass, ${ }^{159}$ the majority opinion by Justice Stewart "presaged a shift in the Court's Fourth Amendment philosophy toward a greater solicitude for privacy flowing from the person." explosion of national concern over gaining control over this growing ability of the government and private investigators to snoop,"161 which rightly could be compared to "today's effort to protect privacy in the face of another explosion of new technologies." ${ }^{\text {,162 }}$ Then, in Berger v. New York, the Court was faced with determining the constitutionality of evidence seized through the use of a bugging device planted in a business office. ${ }^{163}$

In Berger, state agents were investigating allegations that an individual was accepting bribes in exchange for the issuance of New York State liquor licenses. ${ }^{164}$ Although an eavesdropping order was obtained, the majority concluded that the provisions authorizing the order did not satisfy constitutional requirements, because "the broad sweep of the statute is immediately observable." 165 The statute conspicuously lacked any provision requiring that "a particular crime be named." ment that the order disclose a "particular description of the conversations sought." "67 Furthermore, "the length of time eavesdropping was permitted was too extensive,"168 extensions were granted even without proof that the surveillance served the public interest, ${ }^{169}$ no provision required termination of the operation "once the evidence sought was found,"170 and "the statute lacked notice and return procedures."

159 See Gormley, supra note 15 , at $1365 \mathrm{n} .156$ ("The Court found that the contact with the heating duct constituted a physical invasion of the premises.").

160 Id. at 1365 .

161 SCOTT, supra note 20 , at 62.

162 Id.; see also supra note 20 and accompanying text (noting the threat to privacy rights posed by sophisticated information technology).

163388 U.S. 41,45 (1967).

164 See id. at 44-45 (summarizing the facts of the case).

165 Id. at 54.

166 STEPHEN A. SaltzBurg \& DANIEL J. CAPRA, AMERICAN CRIMINAL PRocedure: CASES AND COMMENTARY 373 (5th ed. 1996).

167 Id.

168 Id.

169 See id. (explaining that "extensions of the time period were granted on an insufficient showing" of evidence that they benefited the public interest).

${ }^{170} I d$.

171 Id. 
Clark "recognized that no statute might satisfy its demands, but indicated its willingness to bar much eavesdropping absent a better statute"172 rather than risk exposing individual privacy rights to state-sanctioned abuses. ${ }^{173}$ In the view of the majority, "[b]y its very nature eavesdropping involves an intrusion on privacy that is broad in scope" and warrants particularly demanding regulation. $^{174}$

The Supreme Court ushered in a new era of Fourth Amendment inquiry with Katz v. United States, a case concerning law enforcement agents who planted a listening device on the outside of a public telephone booth to eavesdrop on the defendant's end of the conversation. ${ }^{175}$ In Katz, the Court finally rejected the longstanding view that a Fourth Amendment violation must be coupled with a physical intrusion into "a constitutionally protected area." In In the Court's view, such a formulation of the issue "deflects attention"177 away from a proper analysis of the question as to whether a search has taken place, because "the Fourth Amendment protects people, not places." "178 Although the Court acknowledged that "[w] hat a person knowingly exposes to the public, even in his own home or office, is not a subject of Fourth Amendment protection," it became clear that "what he seeks to preserve as private, even in an area accessible to the public, may be constitutionally protected."179 The decision expressly overruled Olmstead ${ }^{180}$ and Goldman, ${ }^{181}$ asserting that "the reach of [the Fourth] Amendment cannot turn upon the presence or absence of a physical intrusion into any given enclosure."

172 Id.

173 See Berger v. New York, 388 U.S. 41, 64 (1967) ("Our concern with the statute here is whether its language permits a trespassory invasion of the home or office, by general warrant, contrary to the command of the Fourth Amendment. As it is written, we believe that it does.").

${ }^{174}$ Id. at 56.

175 Katz v. United States, 389 U.S. 347, 359 (1967) (holding that the eavesdropping activities constituted an unconstitutional search and seizure within the meaning of the Fourth Amendment).

176 Silverman v. United States, 365 U.S. 505, 512 (1961); see also supra notes 153-58 and accompanying text (discussing the Silverman case).

177 Katz, 389 U.S. at 351.

178 Id.

179 Id. at 351-52.

${ }^{180}$ Olmstead v. United States, 277 U.S. 438 (1928); see also supra notes 137-48 and accompanying text (discussing the Olmstead case).

${ }^{181}$ Goldman v. United States, 316 U.S. 129 (1942); see also supra notes 149-50 (discussing the Goldman case).

${ }^{182}$ Katz, 389 U.S. at 353 (concluding that "the underpinnings of Olmstead and Goldman have been so eroded by our subsequent decisions that the 'trespass' doctrine there enunciated can no longer be regarded as controlling"). 
In a concurrence that lower courts have come to rely on more heavily than the majority opinion, ${ }^{183}$ Justice Harlan articulated his celebrated "expectation of privacy" test for defining legitimate warrantless surveillance by electronic devices. ${ }^{184}$ For Harlan, the application of Fourth Amendment protection is predicated upon a "twofold requirement, first that a person have exhibited an actual (subjective) expectation of privacy and, second, that the expectation be one that society is prepared to recognize as 'reasonable." "185 As the case law developed, it became clear that when interpreting the subjective prong of Justice Harlan's test, "it is not sufficient that [the expectation] be merely reasonable; something in addition is required."186 By way of illustration:

If two narcotics peddlers were to rely on the privacy of a desolate corner of Central Park in the middle of the night to carry out an illegal transaction, this would be a reasonable expectation of privacy; there would be virtually no risk of discovery. Yet if by extraordinary good luck a patrolman were to illuminate the desolate spot with his flashlight, the criminals would be unable to suppress the officer's testimony as a violation of their rights under the fourth amendment. This then is an example of a reasonable expectation of privacy being upset by a patently reasonable "search."

The justification for an individual right to privacy, then, does not derive from an expectation based upon the statistical probability of an intrusion occurring, which "is not really what Katz is all about"; 188 certainly the hypothetical criminals in Central Park rationally considered their transaction to involve little risk of discovery. Rather, the expectation of privacy is intended "to be a basis of differentiating those expectations which are merely reasonable from those expectations which are to be constitutionally enforced due to other social considerations." "189 Thus, the emergent framework established that "[e]xpectations of privacy that society is prepared to recognize as legitimate have, at least in theory, the greatest protection; diminished expectations of privacy are more easily invaded; and subjective expectations of privacy that society is not prepared to recognize as legiti-

183 See Wayne R. LaFave \& Jerold H. ISRael, Crminal Procedure 125 (2d ed. 1992) ("Justice Harlan, concurring, elaborated the point in language which has often been relied upon by lower courts in interpreting and applying Katz .....").

${ }_{184}^{185}$ Katz, 389 U.S. at 361-62 (Harlan, J., concurring).

185 Id. at 361 (Harlan, J., concurring).

186 LAFAVE \& ISRAEL, supra note 183, at 126.

187 Note, From Private Places to Personal Privacy: A Post-Katz Study of Fourth Amendment Protection, 43 N.Y.U. L. REV. 968, 983 (1968).

${ }^{188}$ LAFAVE \& ISRAEL, supra note 183 , at 126.

189 Note, supra note 187 , at 983 (emphasis added). 
mate have no protection."190 In the final analysis, the relevant inquiry revolves around "whether, if the particular form of surveillance practiced by the police is permitted to go unregulated by constitutional restraints, the amount of privacy and freedom remaining to citizens would be diminished to a compass inconsistent with the aims of a free and open society.",191 Therefore, although a literal interpretation of Justice Harlan's test requires that the defendant have an "actual (subjective) expectation of privacy" to invoke constitutional protections, ${ }^{192}$ the Court's further expounding of the doctrine has clarified that the standard strictly depends upon the expectations of privacy that society deems reasonable. ${ }^{193}$

Even more important than the narrow holding restricting the availability of electronic surveillance by law enforcement, the concurring opinion has evolved into a test of general application "even outside of electronic eavesdropping settings," 194 which fundamentally "marks a movement toward a redefinition of the scope of the Fourth Amendment."

\section{The Pendulum Swings Back: Implementing the "Reasonableness" Standard}

Once the Court had issued its definitive statement that the protections of the Fourth Amendment extend to any circumstance in which the defendant possesses a reasonable expectation of privacy, this safe harbor from government surveillance began to shrink. In the early years following Katz, the level of personal privacy extrapolated from the Fourth Amendment surrendered to "a view that used privacy analysis not to expand protected individual interests, but to reduce the scope of the amendment's protections."196 Particularly given the rise in public concern over the rampant growth of illegal drug use during the 1980 s, the Court engaged in a shrewd shift in analysis ${ }^{197}$ - the "expectation of privacy" test was tacitly manipulated de-

${ }_{190}$ Clancy, supra note 136, at 331 (internal quotations and footnotes omitted).

191 Anthony G. Amsterdam, Perspectives on the Fourth Amendment, 58 MINN. L. REV. 349,403 (1974).

${ }_{192}$ Katz v. United States, 389 U.S. 347, 361 (1967) (Harlan, J., concurring).

193 See LAFAVE \& ISRAEL, supra note 183, at 126 (explaining that "the ultimate question under Katz is a value judgment" (internal quotations omitted)).

194 Id. at 125.

195 Id.

196 Clancy, supra note 136 , at 331.

197 See SCOTT, supra note 20, at 63 (noting that "as the war against drugs heated up in the 1980 s, the right of privacy got ... battered, as the courts gave the government and police more leeway in searching for illegal substances, though they might not be so free in doing other kinds of searches"). 
pending upon the nature of the underlying offense. ${ }^{198}$ As one commentator notes, "the existence or non-existence of Fourth Amendment privacy now appears to be dependent (to some extent) upon the subject-matter of the case." 199

When the object of law enforcement surveillance is related to gathering evidence for a criminal trial, the analysis of "reasonableness" has placed a thumb on the scale in favor of the government. A line of cases over the past decade has entrenched an analysis proving unfavorable to personal privacy rights in this context. The 1988 Supreme Court decision in Florida v. Riley $^{200}$ presents an illustrative example. In this case, a county sheriff's office followed up on an anonymous tip regarding a marijuana-growing operation by circling the defendant's property in a helicopter at an altitude of roughly four-hundred feet. ${ }^{201}$ Through aerial naked-eye observations, the law enforcement officer peered through openings in the defendant's backyard greenhouse and concluded that marijuana plants were present inside. ${ }^{202}$ Based upon this information, a search warrant was issued to enter the premises, and the defendant was charged with possession of an illegal substance under state law. ${ }^{203}$

The defendant filed a motion to suppress the evidence, claiming that the warrantless aerial surveillance constituted a violation of his reasonable expectation of privacy against unreasonable searches under the Fourth Amendment. ${ }^{204}$ The trial court granted the defendant's motion, and on appeal, the Florida Supreme Court held that the helicopter surveillance from four-hundred feet established a search for which a warrant was required. ${ }^{205}$ In the view of Florida's highest court, such conduct must be assessed in light of society's standards of reasonableness in order to be considered an

198 See Gormley, supra note 15 , at 1370 ("[T] handed in discounting the 'reasonableness' of the citizen's expectation of privacy where the individual's claim to secrecy or solitude collides with the government's war on drugs and alcohol."').

199 Id.

200488 U.S. 445 (1989).

201 See id. at 448 (describing the aerial investigation by the police).

202 See id. (noting that "[w]ith his naked eye, [the officer] was able to see through the openings in the roof and one or more of the open sides of the greenhouse and to identify what he thought was marijuana growing in the structure").

${ }^{203}$ See id. at 448-49 ("A warrant was obtained based on these [aerial] observations, and the ensuing search revealed marijuana growing in the greenhouse. Respondent was charged with possession of marijuana under Florida law.").

204 See id. at 449.

205 See id. (noting that "[t]he Florida Supreme Court . . . reinstated the trial court's suppression order"). 
unacceptable intrusion into the privacy of the home. ${ }^{206}$ The United States Supreme Court, however, reversed. ${ }^{207}$

In the majority opinion by Justice White, the Court reasoned that although the defendant "no doubt intended and expected that his greenhouse would not be open to public inspection, ${ }^{, 208}$ by leaving the sides and roof of the structure partially open to aerial view, the contents of the greenhouse were "subject to viewing from the air." 209 Thus, the defendant "could not reasonably have expected that his greenhouse was protected from public or official observation from a helicopter ... flying within the navigable airspace for fixed-wing aircraft." ${ }^{210}$ The majority concluded that helicopter flights at four-hundred feet are not "sufficiently rare in this country to lend substance to [the defendant's] claim that he reasonably anticipated that his greenhouse would not be subject to [aerial] observation."211 Accordingly, in the Court's view, he could not possess any reasonable expectation of privacy by societal standards under the Katz search test. ${ }^{212}$

A litany of other cases has similarly rejected Fourth Amendment protection on the grounds that the targeted individual lacked a legitimate $^{213}$ expectation of privacy by society's standards. ${ }^{214}$ Professor Clancy notes that a person has been found to lack an expectation of privacy in the following situations: ${ }^{215}$ when standing in the threshold of one's

${ }^{206}$ See Riley v. State, 511 So. 2 d 282, 288 (Fla. 1987) ("The fourth amendment reflects a choice that our society should be one in which citizens 'dwell in reasonable security and freedom from surveillance."' (quoting Johnson v. United States, 333 U.S. 10, 14 (1948))), rev'd sub nom. Florida v. Riley, 488 U.S. 445 (1989).

${ }^{207}$ See Riley, 488 U.S. at 452.

208 Id. at 450.

209 Id.

$210 I d$. at $450-51$

211 Id. at 451-52.

212 See id. at 450-51 (finding no reasonable expectation of privacy).

213 In cases since Katz, the Court has begun to substitute "legitimate" or "justifiable," for "reasonable," in describing the expectation of privacy test. See, e.g., United States v. Jacobsen, 466 U.S. 109, 121-22 (1984) (holding that law enforcement officials may "seize effects that cannot support a justifiable expectation of privacy without a warrant, based on probable cause to believe they contain contraband." (emphasis added and internal quotations omitted)); Smith v. Maryland, 442 U.S. 735, $743-44$ (1979) ("[A] person has no legitimate expectation of privacy in information he voluntarily turns over to third parties." (emphasis added)). Some commentators claim that the distinction reflects an intention to distance the analysis from "the statistical probability of being discovered in the circumstances," which "is not really what Katz is all about." LAFAVE \& ISRAEL, supra note 183, at 126. Others assert that "those terms do not have a different meaning." Clancy, supra note 136, at 329 n.137.

214 See Clancy, supra note 136, at 331-34 (outlining a hierarchy of protected privacy interests, based on societal standards).

${ }^{215}$ See id. (citing examples where an expectation of privacy was found to be lacking). 
dwelling; ${ }^{216}$ regarding objects and activities in open fields or roads; ${ }^{217}$ from the use of a specially trained drug-sniffing dog to search luggage, ${ }^{218}$ as to observations made from aerial surveillance by an airplane, ${ }^{219}$ even within the curtilage ${ }^{220}$ of the home; $;^{221}$ as to commercial property, in the areas readily accessible by the public to transact business; ${ }^{222}$ and with respect to prisoners while incarcerated. ${ }^{223}$ No legitimate expectation of privacy exists where garbage has been left for collection, ${ }^{224}$ or where a tracking device is

216 See United States v. Santana, 427 U.S. 38, 42 (1976) (finding the threshold of a dwelling to be a public place for Fourth Amendment purposes).

${ }^{217}$ See Oliver v. United States, 466 U.S. 170, 178-81 (1984) (" $[\mathrm{A}] \mathrm{n}$ individual has no legitimate expectation that open fields will remain free from warrantless intrusion by government officers."); United States v. Knotts, 460 U.S. 276, 281 (1983) ("A person traveling in an automobile on public thoroughfares has no reasonable expectation of privacy in his movements from one place to another.").

${ }^{218}$ See United States v. Place, 462 U.S. 696, 707 (1983) (holding that "exposure of [the defendant's] luggage, which was located in a public place, to a trained canine ... did not constitute a 'search' within the meaning of the Fourth Amendment").

${ }^{219}$ See Dow Chemical Co. v. United States, 476 U.S. 227, 239 (1986) (holding an aerial search to be beyond Fourth Amendment protection because "an industrial complex is more comparable to an open field and as such it is open to the view and observation of persons in aircraft lawfully in the public airspace immediately above or sufficiently near the area for the reach of cameras").

${ }^{220}$ For Fourth Amendment purposes, the "curtilage" includes "those outside buildings which are intimately connected with the habitation and in proximity thereto and the land or grounds surrounding the dwelling which are necessary and convenient and habitually used for family purposes." BLACK'S LAW DICTIONARY, supra note 104, at 384.

${ }_{221}$ See California v. Ciraolo, 476 U.S. 207, 213 (1986) (finding an aerial search of the curtilage permissible because the police may lawfully see what may be seen "from a public vantage point where [they have] a right to be").

222 See Maryland v. Macon, 472 U.S. 463, 469 (1985) (finding that there is no "reasonable expectation of privacy in areas of the store where the public was invited to enter and to transact business").

${ }^{223}$ See Bell v. Wolfish, 441 U.S. 520, 557 (1979) (noting that "given the realities of institutional confinement, any reasonable expectation of privacy that a detainee retained necessarily would be of a diminished scope").

224 See California v. Greenwood, 486 U.S. 35, $40-41$ (1988) (suggesting that "[i]t is common knowledge that plastic garbage bags left on or at the side of a public street are readily accessible to animals, children, scavengers, snoops, and other members of the public," and concluding that the defendants "could have had no reasonable expectation of privacy in the inculpatory items that they discarded" (citations omitted)). 
planted in goods sold to a person to monitor their location, ${ }^{225}$ at least until the container enters the curtilage of the person's home. ${ }^{226}$

Although the Supreme Court has yet to speak to the most recent incarnation of sophisticated law enforcement surveillance methods, warrantless thermal imager scanning, ${ }^{227}$ nearly every circuit court that has ruled on this issue has held that the technology falls beyond a person's legitimate expectation of privacy. ${ }^{228}$ Whatever decision awaits the inevitable Supreme Court treatment with regard to thermal imager searches, the symbolic value remains that the rapidly increasing sophistication of surveillance technology has left Fourth Amendment "search" jurisprudence in an unsettled state of flux and mutability. As explained in the discussion that follows, this high degree of uncertainty is precisely the root of the California anti-paparazzi law's unintended consequences.

\section{STATUTORY PRIVACY EXPANSION AND THE FOURTH AMENDMENT SPILLOVER}

Thus far, this Comment has explored the historical developments of remedies against intrusions of personal privacy, and of legitimate law enforcement surveillance in the absence of a warrant. Particular attention has

225 See United States v. Karo, 468 U.S. 705, 712 (1984) ("The mere transfer [to the defendant] of a can containing an unmonitored beeper infringed no privacy interest."); United States v. Knotts, 460 U.S. 276, 285 (1983) (finding that the tracking of a beeper in public to gather the same evidence observable with the naked eye, does not involve a Fourth Amendment violation).

226 See Karo, 468 U.S. at 715 (concluding that the Fourth Amendment is violated when "the Govermment surreptitiously employs an electronic device to obtain information that it could not have obtained by observation from outside the curtilage of the house").

227 Thermal imaging, or "forward-looking infra-red" (FLIR), devices use heat differentials to create a visual display of temperature conditions within a structure. These devices are most commonly used by law enforcement to detect the presence of heat-emitting grow lamps, which are often used to aid indoor marijuana growing operations. See Robert M. Graff, Casenote, United States v. Robinson: Has Robinson Killed the Katz?: The Eleventh Circuit Concludes that Warrantless Thermal Surveillance of a Home Does Not Constitute a Search Under the Fourth Amendment, 51 U. MIAMI L. REV. 511, 512 \& n.11 (1997) (defining a FLIR device as thermal imaging used to "detect the heat emanating from the targeted object as frequencies within the infrared spectrum").

${ }^{228}$ See United States v. Robinson, 62 F.3d 1325 (11th Cir. 1995) (concluding that a FLIR thermal imager search does not violate the Fourth Amendment); United States v. Ishmael, 48 F.3d 850 (5th Cir. 1995) (same); United States v. Myers, 46 F.3d 668 (7th Cir. 1995) (same); United States v. Pinson, 24 F.3d 1056 (8th Cir. 1994) (same); United States v. Penny-Feeney, 984 F.2d 1053 (5th Cir. 1993) (same). But see United States v. Kyllo, 140 F.3d 1249, 1254 (9th Cir. 1998) (concluding that "the details unveiled by a thermal imager are sufficiently "intimate' to give rise to a Fourth Amendment violation"); State v. Young, 867 P.2d 593, 594 (Wash. 1994) (holding that a warrantless FLIR search to detect marijuana production violated the state and Federal Constitutions). 
been paid to the commonality of the "reasonable expectation of privacy" language appearing both in the Supreme Court's constitutional gloss on Fourth Amendment search analysis and the legislative responses to combat paparazzi newsgathering activity. ${ }^{229}$ By applying an adaptation of the constitutional and statutory "accordion phenomenon,"230 this Part concludes that such anti-paparazzi legislation and warrantless search analysis fundamentally will be interrelated-one necessarily will be guided by the other during the course of continued judicial interpretation.

\section{A. "Statutes Revolving in Constitutional Law Orbits"231}

In an effort to codify constitutional norms, a lawmaking body may choose to "utilize the language of the Constitution itself, or ... the language of judicial gloss on the Constitution"232 when proposing legal change. This process of "legisprudence" to reform the law, and to restore what some scholars claim to be bygone constitutional protections through legislative, administrative, and executive means, rather than through constitutional litigation. ${ }^{234}$ By replicating language from judicial opinions, a legislature creates "[s]tatutes [r] evolving in [c]onstitutional [1]aw [o]rbits, ${ }^{2,235}$ which are attempts to resolve perceived deficiencies in the scope of constitutional rights by way of nonconstitutional channels. ${ }^{236}$

This legislative course may produce an economy of effort on two distinct levels: deliberation may be catalyzed "if ready-made judicial concepts seem available and substantively attractive," and additionally, "if and when orbiting choices are made, the corpus of law around the borrowed concept will reduce uncertainty about the enactment's meaning."237 Furthermore,

229 See supra notes 101-23 and accompanying text (noting the element of "reasonable expectation of privacy" in the California law and each of the congressional bills).

230 The "accordion phenomenon" describes the relationship between judicial decisions and statutes that invoke identical constitutional language. See Ira C. Lupu, Statutes Revolving in Constitutional Law Orbits, 79 VA. L. REV. 1, 18 (1993).

${ }^{231}$ Id. at 1 .

232 Id. at 3-4.

233 Julius Cohen, Towards Realism in Legisprudence, 59 YALE L.J. 886 (1950) (explaining the role of judicial law and legislative policymaking in creating legal realism).

${ }^{234}$ See Lupu, supra note 230, at 2 ("']]t has become a commonplace refrain among political progressives that law reform must arrive through legislative, administrative, and executive action rather than through constitutional litigation.").

235 Id. at 1 .

${ }^{236}$ See id. at 3-4 (discussing ways in which legislation expands constitutional protections).

237 Id. at 20. 
the invocation of judicial language "helps to minimize the risk of subsequent invalidation on constitutional grounds." ${ }^{238}$ On the other hand, legislators should be aware that "a judge-made concept may be less suited to the legislative context than initially appears. ${ }^{, 239}$ Even given the compelling justifications for borrowing preexisting judge-made language, the fact remains that " $[t]$ he more a legislative proposal is divorced from the setting that called forth the relevant constitutional doctrine, the greater the risk" of unintended consequences. ${ }^{240}$

Commentators have identified that the phenomenon of orbiting statutes is "far more common than might be expected."241 More importantly, the inclusion of judge-made language in the legislative context creates a peculiar interplay between the legislative and judicial branches of government that eventually may leave unsuspecting lawmakers vulnerable to the unintended consequences of "dynamic statutory interpretation" 242 by the courts. ${ }^{243}$ This so-called "accordion" effect suggests that the ebb and flow of constitutional interpretation by the judiciary inevitably will expand and contract the scope of statutory application. ${ }^{244}$ Put differently, once a statute has been leashed by constitutional terminology to judicial concepts, there will dwell "a tension between judicial supremacy in constitutional matters and judicial obedience to legislative instructions as enacted. 245 Essentially, the court will be torn between interpreting the statute based upon the scope of the legislative intent as construed at enactment, or allowing, over time, the "accordion phenomenon" to reshape the law in accordance with evolving constitutional norms. ${ }^{246}$ In the end, the "use of the judge-made language describing the relevant concept may act as a brake on the advancement of the statutory policy itself." 247 Furthermore, the model predicts that "as bodies of consti-

242 William N. Eskridge, Jr., Dynamic Statutory Interpretation, 135 U. PA. L. REV. 1479, 1479 (1987) (defining dynamic statutory interpretation as that done "in light of their present societal, political, and legal context").

243 See Lupu, supra note 230, at 25-27 (discussing the "power allocation consequences" of drafting statutes in light of decision making).

244 See id. at 18 ("[O]rbiting statutes tethered to the Constitution's own language are vulnerable to the 'accordion' phenomenon, ... by virtue of which the enactment may expand and contract in conformity with changes in judicial statements of constitutional law.").

245 Id. at 26.

246 Id. at 18.

247 Id. at 26. 
tutional and statutory law begin to act reciprocally upon each other, it may become difficult to know which is the tail and which is the dog.,248

\section{B. As Goes the Press, So Goes Law Enforcement}

By drafting a legislative response to intrusive newsgathering that incorporates the Supreme Court's well-established "reasonable expectation of privacy" test, Congress and the California legislature have produced archetypal examples of Lupu's orbiting statutes. ${ }^{249}$ Indeed, members of the California legislature concede that "[t]here is significant case law addressing those circumstances under which a person has a reasonable expectation of privacy, and under which they do not. ${ }^{9250}$ This statement included in the legislative history suggests a clear intent to couple the new anti-paparazzi law with contemporary Fourth Amendment search analysis that courts have entrenched in the case law.

The actual statutory language of the California law in tandem with these comments in the legislative history thus could be viewed as a directive to the courts that the offense of constructive invasion of privacy be defined by the scope of Fourth Amendment "search" analysis. As a result, the constitutional restrictions on surveillance by government agents become applicable to private actors, not by virtue of state action doctrine, but instead from the orbiting nature of the statute. ${ }^{251}$ Reasoning that an individual's "reasonable expectation of privacy" does not turn upon whether her observer is a private or state actor, the California legislature could have concluded that her privacy expectations depend only upon the nature of the surveillance activity itself and therefore are identical in either case. The judicially mimicked language thus enables the legislature to "extend application of constitutional limits beyond state action to private activity" by adopting the same threshold test for defining an offense. ${ }^{252}$

248 Id.

249 See supra notes 97-123 and accompanying text (detailing the California law and congressional bills introduced in response to aggressive paparazzi newsgathering).

250 ASSEMBLY COMM. ON THE JUDICIARY, REP. ON S.B. 262, 1997-98 Reg. Sess. (Cal. 1998)

See, e.g., Lupu, supra note 230, at 9-10 (discussing hate speech codes that apply First Amendment doctrines such as "fighting words" to rules governing private universities).

252 Id. at 4. 


\section{All Bark and No Bite?}

Notwithstanding the benefits of drafting orbiting language, ${ }^{253}$ by expressly adopting the precise text of Justice Harlan's concurrence, the California law invariably is susceptible to the gushing iterations of Supreme Court decisions that apply the Katz "reasonable expectation of privacy" test to innovative high-tech surveillance techniques. ${ }^{254}$ Thus, in one sense the legislative history reflects an intention for the Fourth Amendment "dog"255 to wag the "tail" U.S. Constitution's Fourth Amendment protection against unreasonable search and seizure" as a launching pad. ${ }^{257}$ On this view, the impact of new legislation protecting against intrusive and overzealous newsgathering techniques extends only as far as the waning zone of privacy applied to law enforcement searches of suspected illegal activity. ${ }^{258}$ The narrowing trend for surveillance found offensive to the societally "reasonable expectation of privacy" therefore suggests that liability based on this new breed of legislation is unlikely to materialize into the broad expansion of privacy protection anticipated by its proponents.

Consider the potential impact of the new anti-paparazzi legislation on the following contemporary example of an aggressive newsgathering technique which the law is intended to thwart: the use of helicopters to photograph personal outdoor events, such as the recent backyard wedding of Barbra Streisand and James Brolin in July 1998. ${ }^{259}$ Suppose that the couple, aggravated by the noisy disturbance during their ceremony, had been able to bring suit against the disruptive aerial photographers by invoking the protections of the subsequently enacted California anti-paparazzi law. If the

${ }^{253}$ See supra notes 237-38 and accompanying text (discussing the benefits of utilizing constitutional law orbits).

${ }^{254}$ See Lupu, supra note 230 , at 25-26 (asserting that the problem with orbiting statutes "is the most ubiquitous and potentially pernicious of those associated with statutory interpretation of existing constitutional concepts").

255 Id. at 18 .

256 Id.

257 ASSEMBLY COMM. ON THE JUDICIARY, REP. ON S.B. 262, 1997-98 Reg. Sess. (Cal. 1998).

58 See supra notes 196-228 and accompanying text (discussing the Riley decision and its progeny, which grant broad latitude to warrantless law enforcement searches when drug or alcohol violations are suspected).

259 See Jeanne Beach Eigner, Public Eye, SAN DIEGo UnION-TRIB., July 3, 1998, at E2, available in 1998 WL 4018626 (documenting the "festive sounds of media helicopters" hovering above the wedding); Melissa Schmitt \& Lisa Van Proyen, Streisand Vows Bring Media Crush, L.A. DAIl Y NEwS, July 2, 1998, at N1, available in 1998 WL 3863206 (reporting that "[u]p to 10 helicopters circled above the [neighboring] homes, with some only 100 feet above dwellings"). 
state court frames the statutory "reasonable expectation of privacy" test in accordance with contemporary Fourth Amendment case law, then the Riley holding quickly would dispose of their cause of action. ${ }^{260}$ As discussed above, in that case, the Supreme Court ruled that there is no "reasonable expectation of privacy" from aerial surveillance by a helicopter, and the paparazzi victims therefore would have no cognizable claim under the new law. ${ }^{261}$

Thus, given the amount of Fourth Amendment "search" precedent, substantial case law would promote the view that California's anti-paparazzi law is intended to parallel the search and seizure jurisprudence treating law enforcement use of vision-enhancing devices. ${ }^{262}$ Applying Katz, courts could evaluate the use of such methods in terms of whether the particular defendant "has manifested a subjective expectation of privacy [from visionenhanced observation] under the circumstances of [the] case.,263 Notably, however, this "reasonable expectation" fails when the surveillance occurs in a manner that leaves the subject's activities in plain view from lawfully situated observers without enhancement devices. ${ }^{264}$ Interpreted in this way, the application of the law strictly would be governed by prior Fourth Amendment standards, leaving little in the way of judicial discretion. In sum, rather than providing the broad protections from intrusion sought by anti-paparazzi legislation advocates, the unintended consequence of the law's narrow application would offer surprisingly little in the way of innovative privacy enhancement to those in the media spotlight.

\section{Wagging the Dog}

As the new law and current Fourth Amendment search analysis share identical doctrinal terms taken from current constitutional adjudication, an-

${ }^{260}$ See supra notes 200-12 and accompanying text (discussing the Supreme Court's decision in Riley that held helicopter surveillance to be beyond an individual's "reasonable expectation of privacy").

261 See Florida v. Riley, 488 U.S. 445, 451 (1989) (reasoning, in part, that "[a]ny member of the public could legally have been flying over Riley's property in a helicopter at the altitude of 400 feet and could have observed Riley's greenhouse").

262 See, e.g., Kate Donovan Reynaga, Annotation, Observation Through Binoculars as Constituting Unreasonable Search, 59 A.L.R.Sth 615, 625 (1998) (noting also that "[a] number of jurisdictions have rules, regulations, constitutional provisions, or legislative enactments directly bearing upon this subject").

263 Id. at 626.

264 See id. at 631 (noting one court's explanation that where an individual "conducts activities ... . in such a way that [the activities] are visible by means of unenhanced viewing by persons outside the home, located where they may properly be, such observations transgress no Fourth Amendment protection, because no intention has been exhibited by the householder to prevent the unenhanced viewing"). 
other potentially momentous, unintended consequence lurks behind the statutory language. Consistent with Lupu's warning, the orbiting nature of the statute might lead inescapably to correlative effects on law enforcement surveillance. ${ }^{265}$ Put differently, although the law contains a provision that purports to quarantine law enforcement activities from being infected by invasion of privacy convictions, ${ }^{266}$ the orbiting nature of the statutory language ultimately could have the anti-paparazzi legislation "tail"267 wagging the Fourth Amendment "dog."268 Because the fundamental principle motivating the Katz "reasonable expectation of privacy" test is a judicial determination of societal norms, ${ }^{269}$ the enactment should be viewed as evidence of a communal desire to strengthen individual privacy rights. Indeed, a conviction for media observations, especially those on parallel facts to existing Fourth Amendment case law, should amount to a rejection of the Supreme Court's narrowed interpretation of what constitutes a "reasonable expectation of privacy." Once this assertion is manifested through antipaparazzi convictions, this heightened societal standard for personal privacy rights should be reflected in a broadening of Fourth Amendment "search" determinations during the course of subsequent judicial analysis under Katz.

Consider once again the helicopter surveillance of the Streisand wedding by paparazzi photographers. If the courts were to depart from the confines of Riley and find the media's helicopter intrusion to contravene the statute, then the decision should be interpreted as evidence of evolving societal norms with respect to privacy rights. Because a conscientious application of the Katz test would look to developing societal standards, even the very enactment of the law itself ought to be viewed normatively as compelling evidence of a greater societal interest in protecting an individual's right to personal privacy against, for example, aerial surveillance. ${ }^{270}$ In essence, a guilty verdict on anti-paparazzi charges ought to reflect a departure from the reasonable expectations that existed at the time of the Riley decision, and any future application of Katz to law enforcement helicopter surveil-

265 See supra note 248 and accompanying text (" $[\mathrm{A}] \mathrm{s}$ bodies of constitutional and statutory law begin to act reciprocally upon each other, it may become difficult to know which is the tail and which is the dog.").

266 See supra note 10 and accompanying text (citing the law enforcement exemptions in the California law).

${ }^{267}$ Lupu, supra note 230 , at 26.

$268 I d$.

269 See supra notes $189-93$ and accompanying text (explaining that the Katz test is based on expectations that society deems reasonable).

270 See supra notes 183-93 and accompanying text (discussing the Katz "expectation of privacy" test, and noting that constitutional scrutiny is based upon a standard of societal reasonableness). 
lance should take this into consideration. A faithful application of the Katz test following an anti-paparazzi law conviction on parallel facts also would broaden the scope of societally reasonable expectations of privacy with respect to such intrusions by law enforcement.

Therefore, if the courts deviate, as they may, from established Fourth Amendment jurisprudence when applying the "reasonable expectation of privacy" test against intrusive newsgathering, then the standard would inevitably produce a backlash for warrantless law enforcement surveillance. As legislative efforts to expand a zone of personal privacy against the media are manifested through this new cause of action, the impact on the orbiting language of the $K a t z$ analysis necessarily follows. This fundamentally reciprocal relationship between privacy and law enforcement is precisely the reason why policymakers have hesitated to promulgate protective regulations that may potentially sacrifice effective monitoring of illegal activity. ${ }^{271}$ Proponents of privacy legislation like the California anti-paparazzi law must not fail to recognize that innovative statutory remedies designed to fortify privacy rights necessarily will influence the Fourth Amendment scrutiny test under Katz, which in turn appeals to evolving societal norms for guidance. Legislative expansion of privacy rights and law enforcement search analysis thus proceeds lockstep through judicial interpretation, particularly when drafted as such a tightly orbiting statute. ${ }^{272}$

\section{CONCLUSION}

The rapidly increasing sophistication of surveillance technology-by private as well as state actors-has pitted our individual notions of personal privacy against a backdrop of countervailing societal interests. With regard to private matters, we strive to preserve a modern conception of Warren and Brandeis's "right to be let alone," appetite for photographs and news reports that increasingly are more intrusive. Similarly, in the criminal context, we must balance the constitutional protections of the Fourth Amendment guarantees against the legitimate civil concern for effective law enforcement.

Thus, the underlying legal framework of the California anti-paparazzi law and congressional proposals fundamentally are confused. Each borrows language verbatim from the Supreme Court's "reasonable expectation of

271 See REGAN, supra note 20 , at 16 (noting that in past legislative debates about privacy legislation, "opponents did not challenge privacy as a value but instead focused on the importance of the competing interest ... and on the need to balance privacy against that interest").

272 See id. (identifying "the investigatory need of law enforcement officials" as personal privacy's "major competing interest").

273 Warren \& Brandeis, supra note 14, at 193. 
privacy" test established in $\mathrm{Katz}^{274}$ yet concurrently attempts to prevent law enforcement from being impacted by the evolving societal norms evident in the statutes themselves, and especially in their applications. Consequently, examined in their totality, the orbiting nature of the legislative responses leaves the new law and the Fourth Amendment to struggle over which is the $\mathrm{dog}$, and which is the tail. If we are to believe that the California courts should derive their interpretation of a civil plaintiff's "reasonable expectation of privacy" from existing search and seizure jurisprudence, then this cause of action inescapably is hitched to the shrinking zone of privacy established by recent Fourth Amendment decisions. Invoking this interpretation for defining the scope of actionable claims under the statute, the California legislation offers surprisingly little in the way of innovative personal privacy protection.

If, on the other hand, the new law is to be interpreted independent of such holdings, then the future of law enforcement surveillance in California necessarily is vulnerable to a potentially broadening interpretation of what constitutes an individual's "reasonable expectation of privacy." In the end, the legislative backlash to intrusive newsgathering could be channeled through the courts as a reformulated normative conception of a reasonable zone of privacy, and this necessarily will influence the future of judicial "search" analysis for law enforcement surveillance under Katz.

274389 U.S. 347, 360-62 (1967) (Harlan, J., concurring); see supra notes 183-95 and accompanying text (explaining that the test proposed by Justice Harlan's concurring opinion is relied on more than the majority opinion). 